AperTO - Archivio Istituzionale Open Access dell'Università di Torino

\title{
Political Determinants of State Capacity in Latin America
}

\section{This is a pre print version of the following article:}

Original Citation:

Availability:

This version is available http://hdl.handle.net/2318/1592641

since 2021-03-11T10:34:47Z

Published version:

DOI:10.1016/j.worlddev.2016.07.010

Terms of use:

Open Access

Anyone can freely access the full text of works made available as "Open Access". Works made available under a Creative Commons license can be used according to the terms and conditions of said license. Use of all other works requires consent of the right holder (author or publisher) if not exempted from copyright protection by the applicable law. 


\section{Manuscript details}

Manuscript number

Title

Article type

Abstract
WD_2015_1472

Political Determinants of State

Capacity in Latin America

Full Length Article

In this article, we argue that

pÿboth democracy and governments partisanship have had a bearing

on state capacity in Latin America.

We also maintain that state capacity

is a condition rooted in history

and society: it can be built or purposefully undermined. In particular, in Latin America parties of the left have frequently operated to reallocate social and political clout in favor of underprivileged groups: the inclusion of the latter in the political process helped states to thwart pressures from dominant elites opposing redistribution and tax increases. These mobilized groups have also pushed for universal public services, as high-quality education, health care or public housing, which required well-functioning administrations and an adequate institutional capacity, thus contributing to consolidate stateness in the area. Whereas previous qualitative studies analyzed the mechanisms that relate democracy and political partisanship to state capacity, we test this hypothesis quantitatively. To this end, we estimate the effect over time of democracy, political parties and other socio-demographic factors on a composite measure 


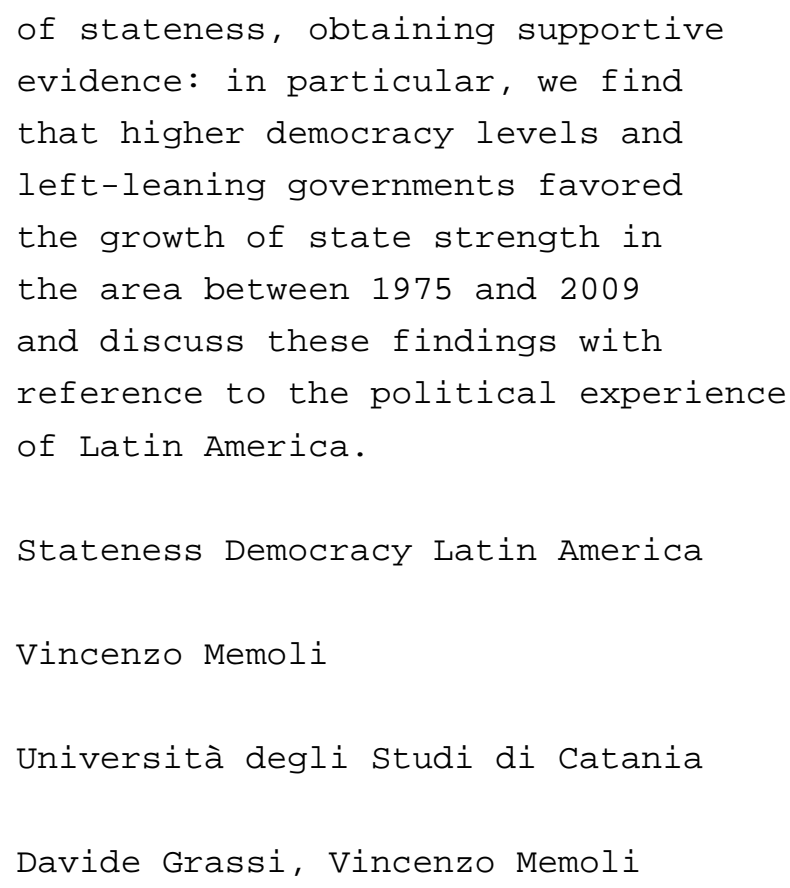

\section{Submission files included in this PDF}

File Type

Cover Letter (with Author Details)

e-Component

Abstract

e-Component

Table (s)

Figure (s)

Conflict of Interest Statement

Manuscript (without Author Details)

\section{File Name}

cover letter.docx

title.docx

Abstract.docx

paper.docx

table.docx

figures.docx

conflict of interest statement.docx

manuscript.docx

To view all the submission files, including those not included in the PDF, click on the manuscript title on your EVISE Homepage, then click 'Download zip file'. 
Dear Editors,

Please find enclosed our manuscript, "Political Determinants of State Capacity in Latin America (1960-2009)”, which we would like to submit for publication in World Development.

In this article, we argue that both democracy and governments' partisanship have had a bearing on state capacity in Latin America. We also maintain that state capacity is a condition rooted in history and society: it can be built or purposefully undermined. In particular, in Latin America parties of the left have frequently operated to reallocate social and political clout in favor of underprivileged groups: the inclusion of the latter in the political process helped states to thwart pressures from dominant elites opposing redistribution and tax increases. These mobilized groups have also pushed for universal public services, as high-quality education, health care or public housing, which required well-functioning administrations and an adequate institutional capacity, thus contributing to consolidate stateness in the area. Whereas previous qualitative studies analyzed the mechanisms that relate democracy and political partisanship to state capacity, we test this hypothesis quantitatively. To this end, we estimate the effect over time of democracy, political parties and other socio-demographic factors on a composite measure of stateness, obtaining supportive evidence: in particular, we find that higher democracy levels and left-leaning governments favored the growth of state strength in the area between 1975 and 2009 and discuss these findings with reference to the political experience of Latin America.

We believe our findings would appeal to the readership of WD for both methodological and substantive reasons.

We look forward to hearing from you at your earliest convenience.

Davide Grassi and Vincenzo Memoli

\section{Short Bio}

Davide Grassi is Associate Professor of Political Science at the University of Torino. He is currently investigating democratic transitions and their consequences, by means of both qualitative and Configurational Comparative (CCM) methods. He has published books on the topic of democratization in the major areas of the world and several articles on various national and international Journals, such as the Journal of International Relations and Development, Latin American Politics and Society, Swiss Political Science Review, Revue Internationale de Politique Comparée and Italian Political Science Review.

Vincenzo Memoli is Assistant Professor at Università degli Studi di Catania. His main research interests include democracy, public attitudes and public opinion. Hi is coauthor of Why Policy Representation Matters: The consequences of ideological proximity between citizens and their governments (Routledge 2015) and has a forthcoming book (with D. Di Mauro) Europeans with National Eyes. Attitudes towards EU in time of crisis (Palgrave 2016). His articles have appeared in the Acta Politica, British Journal of Political Science, International Political Science Review, Governance, The International Journal of Press/Politics, West European Politics, and other peer-reviewed journals. 
Author's e-mail address

Grassi Davide: davide.grassi@unito.it

Memoli Vincenzo: memoli@unict.it 
Political Determinants of State Capacity in Latin America 
Abstract:

In this article, we argue that both democracy and governments' partisanship have had a bearing on state capacity in Latin America. We also maintain that state capacity is a condition rooted in history and society: it can be built or purposefully undermined. In particular, in Latin America parties of the left have frequently operated to reallocate social and political clout in favor of underprivileged groups: the inclusion of the latter in the political process helped states to thwart pressures from dominant elites opposing redistribution and tax increases. These mobilized groups have also pushed for universal public services, as high-quality education, health care or public housing, which required well-functioning administrations and an adequate institutional capacity, thus contributing to consolidate stateness in the area. Whereas previous qualitative studies analyzed the mechanisms that relate democracy and political partisanship to state capacity, we test this hypothesis quantitatively. To this end, we estimate the effect over time of democracy, political parties and other socio-demographic factors on a composite measure of stateness, obtaining supportive evidence: in particular, we find that higher democracy levels and left-leaning governments favored the growth of state strength in the area between 1975 and 2009 and discuss these findings with reference to the political experience of Latin America. 
In this article we argue that both democracy and governments' partisanship have a bearing on state capacity in Latin America: in particular, we find that higher democracy levels and left-leaning governments favored the growth of state strength in the area between 1975 and 2009. Whereas previous qualitative studies have analyzed the mechanisms that relate democracy and political partisanship to state capacity, we test this hypothesis quantitatively, obtaining supportive evidence. Our work is organized as follows: in the next section, we discuss the relevant literature, then define our main dependent, independent and control variables, paying special attention to the thorny concept of state capacity. Subsequently, we submit our main hypotheses and summarize the mechanisms at work. Finally, we estimate the effect over time of democracy, political parties and other socio-demographic factors on a composite measure of stateness; discuss these findings with reference to the political experience of Latin America; and underline our contribution to the ongoing debate. Conclusions, as usual, wind up the analysis.

Social science literature has mostly considered democracy and stateness as causally independent or it has taken the latter to be a precondition for the former (Wang \& Xu, 2015). The rare works analyzing the bearing of democracy on state capacity generally underscore a positive association: the superior political accountability of democracy lowers corruption 
and the risk of property expropriation and strengthens bureaucratic quality and the rule of law, thus improving overall state capacity (Adserà, Boix \& Payne, 2003). As a result of vigorous political competition, for instance, various non-partisan state organs and policy reforms aimed at increasing government efficiency were implemented in Hungary, Lithuania, Poland and Slovenia after their democratic transitions (Grzymala-Busse 2007). In Africa, as well, democracy has been empirically associated to several components of state capacity as rule of law, effectiveness, accountability and control of corruption (Bratton, 2008). In Malaysia, Indonesia and the Philippines, competitive elections have facilitated state-building by stimulating the formation of stronger political parties; a more vigorous state commitment to voters' registration; and the imposition of centralized authority over societal strongmen (Slater, 2008). In short, the historical influence of parliamentary democracy has been considered to be an unusually stable predictor of both the legal and fiscal capacities of the state (Besley and Persson, 2009): democracy strengthens stateness by enhancing government responsiveness to citizens; by facilitating the diffusion of information between policy-makers and voters (Bueno de Mesquita et al., 2015); and by increasing political contestation (Wang and $\mathrm{Xu}, 2015$ ).

The influence of democracy, however, is still controversial as strong developmental states have existed under 
authoritarian regimes in Asia (for instance in Taiwan and South Korea). In addition, the assertion that democracy strengthens the consolidation of state institutions must confront the sensible objection that democracy can subsist only after a minimally functional state is already in place (Carbone \& Memoli, 2015). Thus, analyzing African regimes in the early 1990s, Bates (2008) claims that electoral competition and state failure go together since, during democratic openings, incumbents are less secure about their tenure and rewards from predation multiply, encouraging domestic conflicts and state collapse. In new democracies, in addition, objectionable politicians might emerge who view the new democratic politics as a "one-time opportunity to get rich" (Svolik, 2012). Others, finally, point at a non-linear relationship: Charrón and Lapuente (2010) claim that deprived countries enjoy higher 'administrative capacity' under despotic rule, while richer countries perform better under democracy. Bäck and Hadenius (2008) similarly contend that the association between level of democratization and 'administrative capacity' is negative at low levels of democratization, but positive at higher levels. Administrative capacity declines initially as the political system opens and a plurality of social and political actors undermine authoritarian controls from above: however, as mature and more stabilized democratic regimes develop, bottom-up mechanisms of policy 
control emerge that help attain the highest levels of administrative capacity.

In Latin America, democracy has not been typically studied as a determinant of state capacity, but rather as one of its outcomes: thus, poor democratic conditions are often explained as a consequence of local states weakness. Accordingly, among the key determinants of state capacity scholars mention particular historical heritages; features such as the amount of trust in public and private institutions; economic and social inequalities; and globalization (Centeno, 2009). Cárdenas, however, singles out political inequality as one of the factors that possibly account for the extraordinarily low state capacity in the region, in conjunction with economic inequality, regional struggles, and civil war (2010). Others maintain that democratic rule strengthens the capacity of the state to provide citizens with fundamental social services, by encouraging politicians to reach the poor and those more exposed to risk, and these latter to organize (Haggard \& Kaufmann, 2008).

Whether and how in Latin America state capacity has been shaped by democratic rule, however, remains an open question. Acemoglu and Robinson (2008), for instance, notice that the trend toward greater democracy in the area has not been accompanied by a similar change in state capacity, which has remained especially low. They argue that, even if de jure democratic institutions have been established (political rights, 
voting and checks on the executive), the political balance has not changed for the presence of crucial de facto powers, as dominant social groups. Likewise, Cheibub (1998) underlines that, from 1970 to 1990 , governments' extractive capacity has not been much stronger in democracies than in authoritarian regimes. Grassi and Memoli (forthcoming), finally, find that between 1995 and 2009 democracy has weakened the negative effects of autocracy on state capacity, but it has been insufficient, by itself, to promote its strengthening. There are, in short, several objections to the view that democracy always advances stateness: antagonistic electoral competition can undermine a state and democratic petitions may overburden and deteriorate political institutions (Hagopian \& Mainwaring, 2005). Rather than contributing to reinforce state institutions and increase their effectiveness, therefore, the acceptance of formally democratic institutions may actually corrode or disintegrate state authority and public services.

State capacity, on the other hand, is a condition rooted in history and society: it can be built or purposefully undermined (Grassi \& Memoli, forthcoming). In most instances, states that achieved vigorous stateness in time did not have the necessary ability nor the right bureaucracies to do so in the beginning: where a political leadership committed to growth and equality had reached a settlement with domestic actors to define a common policy framework, a developmental and welfare- 
improving bureaucracy was typically created to support it (Haggard \& Kaufmann 2008). In other cases, a weaker state capacity (the limited power to levy taxes, for instance) was the result of the veto power exercised by powerful social groups that successfully resisted increases in the tax load (Huber \& Stephens 2012, p. 41). Parties of the left generally operate to reallocate social and political clout in favor of underprivileged groups: the inclusion of the latter in the political process helps states to thwart pressures from dominant elites opposing redistribution and tax increases. These mobilized groups push for administratively challenging universal public services, as high-quality education, health care or public housing, and the institutional capacity necessary to provide them, thus contributing to consolidate stateness. Parties of the right, in turn, often advocate order and legality, since crime and violence jeopardize business investments and growth and are usually aimed at affluent individuals. A stronger state, in addition, allows for an effective enforcement of property rights, duly supported by smoothly functioning legal institutions, and contributes to restrain widespread corruption. Where established safeguards of this kind are absent, insecurity and unpredictability arise, which endanger new investments, the creation of jobs and the development of business (Fukuyama, 2007). 
Finally, electoral competition crucially interacts with ideological preference. When election results are uncertain, regardless of ideological orientation, parties may be driven to embark on policies that they might otherwise ignore, for the sole purpose of gaining or retaining power (Haggard \& Kaufman 2008, p. 360). Policies may be endorsed to capture the independent voter at the center and will be more moderate, or reformist, than the ideological position of each party implies. Consequently, left-wing and right-wing executives may become more similar: the former cannot support their favorite policy of welfare state extension because of budget limitations; the latter cannot adopt their favorite policy of cutbacks because their constituencies have become attached to welfare state programs (Schumacher \& Vis 2009). To sum up, the contribution of political partisanship to the construction of state capacity in Latin America is a question that demands an empirical answer.

\section{State Capacity}

State capacity is a thorny concept, arduous to define and operationalize: in fact, there is greater scholarly agreement on key features of the state than on how to operationalize such features or the concept of the state itself (Carbone 2013, p. 6). In the last few years, however, political scientists and sociologists have engaged in an extensive and critical debate: 
while failing to yield a common position, the ongoing discussion suggests points of convergence (see the special issues of Studies in Comparative International Development, 2008; and Revista de Ciencia Política, 2012). ${ }^{1}$ Definitions of state capacity often rest on the ability of state institutions to effectively implement official goals (Sikkink, 1991). This approach solves a first significant problem, namely the normative definition of what the state ought to do or how it ought to do it, and underlines the fact that capable states may organize the economy and society in different ways. Thus, in the aftermath of the neoliberal cutbacks in state intervention and bureaucracy in Latin America, one should be able to avoid confounding minimal but capable states as Chile with essentially weaker states. A second recurring theme has to do with Mann's “infrastructural power” concept, that is "the institutional capacity of a central state, despotic or not, to penetrate its territories and logistically implement decisions” (2008). Mann’s contribution underlines “the question of the state's authority over territory" and "whether governments can implement policies, including the provision of public goods” (Fortin, 2010, p. 656). In short, the infrastructural power of the state may be read as the ability to translate policy choices into outcomes. In addition, many authors also typically indicate state capacity through at least one of three constituent elements: the ability of a state to impose a degree of internal political order, by way of an exclusive control over the means of coercion; the 
proper workings of a basic administrative apparatus; and the capacity to extract revenue from its citizens. ${ }^{2}$

Weber famously defined the state in terms of its coercive capacity, based on the monopoly of the legitimate use of physical force within its territory (Weber, 1978). Imposing political order requires a state to secure its frontiers, defend domestic order and apply laws and policies by restraining violence, i.e. to control the territory by both suppressing and preventing internal conflict and defending the borders from external invasion. A basic administrative apparatus is working properly when a professional and insulated bureaucracy is able to plan and develop policies and deliver public goods and services, which implies technical skills, competent civil servants, limited public corruption, and an effective influence across state territory. Extractive capacity, finally, indicates the ability of the state to extract resources from society, mainly in the form of tax and implies a series of critical competences and skills: instruments to access population; means to assemble and organize complex information; the possibility to count on lawabiding civil servants; and ways of assuring popular compliance with tax policies (Hanson \& Sigman, 2013, p. 4). ${ }^{3}$

The operationalization of state capacity has also been controversial, but some points of convergence are also discernible. Most agree that any single variable is unlikely to adequately capture its multidimensional nature (Hendrix, 2010, 
p. 283). Composite indexes of the concept should also avoid incorporating potential causes, as lack of democracy, or expected consequences, as humanitarian disasters (Gutiérrez, 2011; Mata \& Ziaja, 2009; Soifer, 2012). Finally, the ideal data should be based on time-series cross-national measurements of stateness that ensure wide-ranging geographic and temporal coverage, enabling researchers to take advantage of variations across space and time. Based on these reflections, we decided to use the State Capacity Dataset (1960-2010) elaborated by Jonathan Hanson and Rachel Sigman (2013), which covers up to 174 countries for the period 1960-2010. The dataset rests on the three main components examined above: coercive, administrative and extractive capacities, which are measured in turn by 24 main indicators. By way of latent variable analysis, finally, the authors identify a series of underlying factors that signify overall state capacity.

More precisely, coercive capacity is indicated by four sets of data, beginning with military personnel and expenditures. Yet, a sizeable military force may signify war or domestic insecurity, both of which lessen state capacity. Consequently additional data has been added, as the extent to which the state has a monopoly on the use of force; is directly involved in committing violence; or is present in the territory, by looking for instance at the extent to which land is mountainous and therefore arduous to reach. Administrative capacity is evaluated 
also based on four groups of data: the ICRG (International Country Risk Guide) Bureaucratic Quality Index; an assessment of census frequency, which denotes both the capacity to gather data and effective territorial control; measurements of contract intensive money, which stand for the state capacity to police economic exchange; and an additional series of indexes related to administrative capacity and civil service value, such as the Weberianness Index elaborated by Rauch and Evans (2000). Extractive capacity, finally, is initially measured by tax revenues as a percentage of GDP. In order to distinguish between policy choices and extractive capacity, however, additional measures were added, as the ratio of tax revenues originating from income, domestic consumption and property taxes relative to revenue coming from international trade, as custom duties. The higher the proportion of the former, which require a more structured bureaucratic apparatus, the greater is the expected level of extractive (and administrative) capacity of the state. Other indicators, finally, show the link between actual revenue collection and the expected tax yield, given GDP per capita, mineral production, exports and additional relevant factors.

\section{Independent and control variables}

We decided to use a minimalist notion of democracy to avoid merging attributes of political authority and state qualities 
(as capacity), since our objective is to disentangle this relationship. Our procedural definition is based on universal suffrage; free, transparent and competitive elections; and the defense of crucial civil and political rights (along with the presence of alternative sources of information). Formal democratic institutions must also be sovereign (Dahl, 1989). Consequently, democracies do not comprise hybrid or 'electoral authoritarian' regimes, since these do not convene free and fair elections, an essential requirement of this type of government (Diamond, 2002; Levitsky \& Way, 2002). Democracies, finally, may also be imperfect and incomplete: 'defective' democracies only partially safeguard political rights (Merkel, 2001); 'illiberal' democracies inadequately protect civil rights and the rule of law (Zakaria, 1997); and 'delegative' democracies are insufficiently responsive to citizen choices, poorly constrained by government agencies and not respectful of the rule of law (O'Donnell, 1994). To measure democracy, we resorted to the Polity IV data, on a scale that runs from -10 (full autocracy) to +10 (full democracy): the curators of the Polity IV dataset distinguish among ‘autocratic regimes'; ‘anocracies'; and 'democracies'. 'Anocracy’ is a term used to describe a regime type that is characterized by inherent qualities of political instability and ineffectiveness, as well as an "incoherent mix of democratic and autocratic traits and practices." (Marshall \& Cole, 2014). These regimes are further differentiated among 
'closed' and 'open' varieties: the former are characterized by Polity IV values comprised between -5 and 0 ; the latter by values ranging from 1 to 5 . Values of 6 , or larger, denote democratic regimes, while values included between -10 and -6 identify autocratic regimes. ${ }^{4}$

Democracy impacts stateness by reducing violence and corruption and increasing administrative efficacy. It lowers violent conflict by offering institutionalized communication channels with political adversaries, by incorporating them into the debate and by yielding to some of their petitions. ${ }^{5}$ By making the government accountable, citizens are more likely to identify with democracy and the state and have fewer reasons for violent opposition. Independent civil society groups monitor and assess state functioning and cooperate with the state to recommend new policy ideas. Finally, by making elected officials and administrators responsible, democratic processes and sanctions restrain incompetence, arbitrariness and the diffusion of bribery (Carbone, 2013). We do not rule out, however, that the relationship between democracy and stateness may assume a non-linear form: as recalled above (Bäck \& Hadenius, 2008), different political regimes may have a diverse impact on stateness.

We classified Latin American parties based on a left/center-left versus right/center-right dichotomy, as in the more industrialized countries, following the categorization 
suggested by Coppedge (1997; Huber et al. 2012 for an update). ${ }^{6}$ Coppedge made use of experts who classified parties, along this dimension, into left; center-left; center; center-right; right; and personalist. Accordingly, parties of the right (for instance, Brazilian ARENA) attracted the successors of nineteenth century traditional elites; fascists and neo-fascists; and the conservative military (Coppedge, 1997, p. 8). Center-right parties (Argentine UCD) "targeted middle- or lower-class voters in addition to elite voters, by stressing cooperation with the private sector, public order, clean government, morality, or the priority of growth over distribution” (Ibid.). Coppedge classified as centrist (Argentine UCR) parties that "stressed classic political liberalism, the rule of law, human rights, or democracy, without a salient social or economic agenda”. Among them are "governing parties whose policies are so divided between positions both to the left and to the right of center that no orientation that is mostly consistent between elections is discernible” (Ibid.). Changing partisan orientation, center-left parties (Venezuelan Acción Democrática) “stress justice, equality, social mobility, or the complementarity of distribution and accumulation in a way intended not to alienate middle or upper-class voters” (Coppedge 1997, p. 9). Left parties (Partido Socialista de Chile; Communist parties) “employ Marxist ideology or rhetoric and stress the priority of distribution over accumulation and/or the exploitation of the working class by 
capitalists and imperialists and advocate a strong role for the state to correct social and economic injustices”. (Ibid.: 10). ${ }^{7}$ Finally, parties are catalogued as personalist (Peruvian Cambio 90 or Bolivian Movimiento al Socialismo) if they "base their primary appeal on the charisma, authority, or efficacy of their leader rather than on any principles or platforms, which are too vague or inconsistent to permit a plausible classification of the party in any other way" (Ibid.). We use a continuous variable to measure the partisan orientation of governments (Executive Partisan Balance, EPB) during democratic periods. ${ }^{8}$ When the values of EPB increase, the ideological leaning of the Executive moves right (Huber et al., 2012). We also account for the fact that state capacity needs time in order to change.

Scholars' opinions (and the available evidence) on the role of partisanship in shaping state capacity are mixed. Incumbency of left parties is central for welfare state development according to comparative historical evidence (Huber \& Stephens, 2012). More recently, in line with their major political objectives, Left governments have made efforts towards extending democracy and citizens’ rights, restoring state capacity, freeing while regulating markets, and building a satisfactory technical and political environment for skilled policymaking (Bresser-Pereira, 2001). Other investigations link vigorous mass mobilization and left-party rule to the progress of infrastructurally accomplished welfare states. However, 
alternative studies point at the consolidation of state capacity under right-leaning executives (Fukuyama \& Colby, 2011; Rangel, 2005) or to a process of ideological convergence by major political parties and governments that blurs partisan and policy differences (Haggard \& Kaufmann, 2008). As a result, we leave an initial answer to this issue to our empirical analysis.

Our model is completed by a number of control variables. To start with, we suggest that past levels of state capacity have a bearing on current stateness levels. It has been argued (and extensively recognized) that state capacity is path dependent and varies slowly: critical junctures in the past place institutional arrangements on paths or trajectories, which are then very difficult to alter (Centeno, 2009; Soifer, 2012). Actual degrees of state strength are therefore strongly affected by previous ones: consequently, we added a stateness difference variable calculated on stateness values prevailing 15 years earlier. ${ }^{9}$ We also added political controls: democratic duration and presidentialism. We believe that democratic duration is associated with stateness, since time allows democratic institutions and practices to get established and to take root; is necessary for democratic norms to develop and have an impact; and may encourage more participation and influence for deprived groups not only through parties, but also through the development of civil society and nongovernmental organisations (Nelson, 2007, p. 89), all of which aid the completion of state 
consolidation. ${ }^{10}$ Presidentialism, on the other hand, is usually thought of as a direct and effective way to govern and a weaker form of veto power in the political process, compared to parliamentarism (Huber and Stephens, 2001, p. 55). Since we expect political systems characterized by stronger veto points in the policy process to slow down the expansion of stateness during the period of observation, we believe that presidentalism should have the opposite effect.

In order to test a possible spurious relationship between our main variables we also incorporate levels and growth of economic development: in fact, both state capacity and democratic governments might be the upshot of economic development over time. A host of authors argue in favor of an independent effect of economic development on state capacity. Pellegrini and Gerlagh vindicate that wealth fosters state capacity, since richer countries may afford better institutions and administrative structures and many factors associated with affluence, as levels of urbanization or schooling, lessen the social acceptance of corruption (2008, p. 250). Saylor contends that the quest for private profit is a potent state building cause: when pursuing profit during booms, export-oriented actors repeatedly strive for new state-supplied public goods, whose delivery encourages the expansion of state capacity (2012). Inequality is one of the major problems faced by the Latin American subcontinent: while poverty has been alleviated in 
recent years, inequality has proven more difficult to overcome. Higher inequality has been associated with lower stateness: historians Engerman and Sokoloff contend that inequality has been detrimental to the emergence of legal and fiscal capacity in Latin America (2002). Cárdenas and Tuzemen also find that higher levels of income inequality lead to lower investments in state capacity (2010, p. 1-45).

Large oil rents (whenever both the state and democracy are not yet solid) deteriorate state capacity because they exempt the state from establishing an efficient tax collection system. Thus, in these countries, governments tend to be unaccountable to the general population and people, in turn, are less likely to demand accountability and political representation. Oil wealth, in addition, fuels patronage, which dilute demands for representation and accountability (Karl, 2004). ${ }^{11}$ Where ethnic fractionalization is high, elected governments must strike a balance between insertion of minority groups and protection of governing effectiveness (Ben-Meir, 2006); citizens have usually lower confidence in political institutions; and democracy is less likely to become established (Sojo, 2011). Accordingly, it is reasonable to link high fractionalization to lower stateness. ${ }^{12}$ Larger territories, finally, may also prove challenging to govern, since (ceteris paribus) vertical integration and horizontal coordination become more demanding (Herbst \& Mills, 2006). 


\section{Data, methods, findings' illustration and discussion}

We chose Latin America to ensure comparability within a most similar research design: the subcontinent, in addition, represents an ideal testing ground for our main hypotheses, the bearing of political dimensions on state strength. In this area, democracies are plentiful and differ in quality (unlike, for instance, the Middle East), while local parties' ideologies may be sorted along a right-to-left continuum which meaningfully structures politics and political struggle (as opposed, for instance, to the political beliefs of most African and Asian parties). Political views that cause stable and intelligible policy choices, in fact, even if less easily discernible than in the developed West, are crucial for an enquiry on the potential connections between political parties acting in a democracy, partisanship and state capacity, and justifies the choice of the subcontinent to assess our research questions.

Our analysis embraces all Latin American countries, observed between 1960 and 2009: we originally considered 26 countries in total, 14 belonging to Central America and 12 to South America. Missing data problems forced us to exclude seven of them from our final report. ${ }^{13}$ Our analysis is based on a pooled cross-sectional time-series. The advantage of longitudinal panel information, compared to cross sectional information, consists in its potential for an analysis of social, 
political and economic dynamics at different levels. We employed different random effects longitudinal regression models on a long unbalanced panel dataset, using the software STATA. ${ }^{14}$

We begin with a descriptive analysis of the trend of stateness (Fig. 1). During the period of observation (1960-2009), our measure of state capacity has increased everywhere, especially in countries where the quality of democratic governments has been intermediate to strong and the left has exercised power for significant periods of time, as in Chile, Trinidad and Tobago, Uruguay, Brazil and Costa Rica. However, equal or slightly less prominent increases in state strength have also occurred where governments were controlled equally by left and right parties, as in Panama, or mostly by parties of the right, as in Colombia and Guatemala. In addition, left executives have played a role where state capacity has increased the least, as in Guyana, Jamaica or Venezuela, countries characterized by diverse levels of democratic quality. In short, no clear indication on the possible links between stateness, democracy and political partisanship comes from a reading of these data alone.

This impression is strengthened by a graphic assessment of the way stateness has changed over time in specific countries: in Chile the authoritarian Pinochet era (1973-1990) is associated with an increase in stateness, especially until 1981 (Fig. 2). Democracy further intensifies state capacity, but the more 
prominent rise occurs under moderate Christian democratic presidents (1990-2000) rather than under their progressive colleagues within the Concertación alliance (2000-2010). In Uruguay the military period (1973-1985) also corresponds to an increase in stateness, which is maintained and enhanced by the following democratic governments, led by centrist and conservative Colorado and Blanco presidents (1985-2005): their contribution to state capacity is difficult to distinguish from that of the Frente Amplio (Fig. 3). In other cases, as in Paraguay, the growth of state capacity coincides with the authoritarian rule of General Stroessner, especially between 1960 and 1981, while democratic governments (under the guide of the conservative Colorados) were not able, at least until 2009, to improve the stateness scores reached in 1981 by the tyrant (Fig. 4). In the case of Venezuela, finally, improvements of state capacity were experience both under conservative and progressive democratic governments, as with Copei (Comité de Organización Política Electoral Independiente) president Caldera between 1969 and 1974 and MVR (Movimiento V [Quinta] República) president Chàvez between 2002 and 2009 (Fig. 5). Again, it is hard to discern a clear-cut pattern emerging from this information.

A more refined investigation is in order. In Tab. 1 we analyze 3 models: in the first two, we focus separately on levels of democracy and the impact of executives’ ideological leanings, along with control variables. Subsequently, we estimate the 
aggregate bearing of these variables on the dependent variable. Specifically, in the first model we regress the indicator of state capacity against levels of democracy (in linear and quadratic forms) controlling for context variables: a lagged (fifteen years) stateness variable; a measure of democratic duration (again in linear and quadratic forms); level of economic development; economic growth over the previous 5 years; oil rents; Gini values; form of government and ethnic fractionalization. Results show that democratic quality (but not democratic duration) has contributed to strengthen stateness in the area between 1975 and 2009 (Rsq=0.667). In the second model, we insert executive partisanship which shows a curvilinear association with stateness: moving from left to right governments, stateness increases first and then declines, as expected (Rsq=0.647). In model 3, finally, we incorporate levels of democracy and executive partisanship along with our control variables and observe that our main results are confirmed (Rsq=0.674). More precisely, authoritarian governments and both closed and open anocracies are associated with negative stateness: however, as political regimes get freer and more effective, approaching the threshold of democracy in the Polity IV scale (value 16 in Fig. 6), the impact on stateness becomes positive.

Our main findings suggest that democratizing always benefits stateness: however, the impact of regimes becomes positive only when a significant level of political opening is 
reached. Democracy fosters an efficient state through a series of mechanisms that reduce violent conflict and establish forms of steering and control from below, as a free press and an independent civil society; by way of instruments of policy control that promote administrative capacity; and by institutionalized procedures and incentives that reinforce the accountability structure. Yet, democratic institutions must be put in place and be effective. Empirical results fit our predictions on executive partisanship as well (Fig. 7). Moving from left executives (points 0 and 1) to executives of the center-left (points 2 and 3) the impact of partisanship proves positive but decreasing. Under center right and right executives (points from 4 to 7) the impact becomes negative, but the relationship is statistically significant only for right-wing executives. ${ }^{15}$ In short, not only we confirmed the expected causal direction, but also determined that the effects of our independent variables developed at values identifying relevant qualitative conditions: democratic governments in the Polity IV scale and left and leftleaning governments in Coppedge’s taxonomy (Figures 6 and 7). In addition, state capacity at 15 years shows significant and positive, meaning that earlier stateness levels have a bearing on current levels. Both economic development and economic growth have a positive sway on stateness, as expected, while oil rents display a positive sign, against predictions: instead of smothering political representation and weakening tax collection 
as the prevailing theories anticipate, oil proceeds appear to have stimulated stateness in the area (especially in Brazil, Mexico, Venezuela, and Colombia) possibly through public investments, expenditures and the overall contribution to economic wealth, or else these positive effects have been stronger than those classically underlined by the literature. Presidential regimes, finally, look more favorable to state capacity that parliamentary ones, as foreseen, while democratic duration, ethnic fractionalization and Gini values fail to reach statistical significance.

In short, the argument presented here is that democracy and left governments promote the limitation of social and economic prerogatives, thus contributing to a strengthening of state capacity. The adoption and implementation of governments’ policies face constraints, including policy capture by powerful social factions and opposition by organized interest groups. Democratic regimes with good development outcomes attempt to surmount such limitations by engaging citizens more actively with the purpose of building the needed consensus for state policies: such participation improves the capacity to allocate resources more equally and effectively and reduces the costs involved in policy enforcement. Thus, the recognition of the right to question policies and make petitions has been crucial to the strategies of state capacity building in Latin American democratic regimes. Whereas democracies offer chances for 
participation and contestation in the policy process, however, redistributive results cannot be taken for granted: it is through the decisive involvement of left governments that the mismatch between political and social powers has been drastically reduced and state strength has increased in the area. This argument emphasizes the importance of reallocating social and political power in favor of subordinate groups so as to construct bureaucratic capacities that reinforce both growth and redistribution and defeat pressures from privileged strata, which repeatedly defy redistributive policies. Social transfers are a vital component of such agreements.

Accordingly, the states usually classified by the literature as the most capable in the region have tended to coincide with the most vigorous democracies, as Costa Rica and Uruguay, along with Chile and Argentina (Cárdenas, 2010; Centeno, 2009). In the first three, progressive parties intent on redistribution were crucial in the process of welfare state building (Grassi, 2014). More generally, redistributive politics have been more inclusive when rural-urban alliances that included a large part of the working poor have been struck, permitting to expand welfare rights to most citizens. In these countries, progressive political parties have promoted the adoption of social rights, and groups have connected with the state as rights-bearing citizens rather than clients. Disputed elections, sometimes leading to alternation in power, encouraged 
these parties to maintain their social movement features, which in turn showed crucial for upholding sympathetic links with the poor. In addition, at the end of the 1990s, a 'new left' has appeared in the subcontinent, which assumed the essential tenets of market economics, while approving reforms such as the enactment of welfare plans for the underprivileged; a new concern for public safety; a more dynamic role for the state as overseer and arbitrator between capital and labor; the expansion and improvement of public services; and the introduction of a more progressive tax system (Barrett et al. 2008, 22).

Our conclusions are partly in line with, and partly supplement, the scant literature on these issues. We developed the only previous analysis on this topic in Latin America (Grassi \& Memoli, forthcoming) suggesting that, over extended periods of time, democracy has played a greater role than previously acknowledged: from 1975 to 2009 democratic governments, compared to autocracies and anocracies, did contribute to make stateness more robust. We also confirmed the impact of executives' partisanship, showing in greater detail the bearing of different political leanings on state capacity. Previous authors had argued that the weakness of the state in Latin America depended on pervasive economic inequality: economic inequality, however, is also a reflection of left parties’ weakness, and we illustrated the mechanisms relating these parties to state capacity (Cárdenas, 2010). For Haggard and Kaufmann (2008), 
democracy may fortify the state by endorsing more progressive social welfare schemes. In the region, in turn, more progressive social welfare systems have been linked to the existence of a stronger left: left governments have more forcefully sponsored redistributive welfare and checked the intentional boycotting of critical state powers, such as tax extraction, which infringed upon the privileges of local elites (Grassi, 2014).

Tab. 1 Here

The case of Chile may help illustrate the argument. The left-leaning governments led by presidents Lagos (2000-2006) and Bachelet (2006-2010) deeply reformed education, public health, social security and pensions, greatly enhancing social assistance for Chile's poorest citizens; approved a series of laws on integrity (2003) and transparency (2009) in the Public Administration; diminished the number of civil servants directly chosen by the Executive; and inaugurated a Senior Management Service System, whose access was regulated by competitive public exams, making civil service careers more professional. In 2005, a reform also enhanced the Constitutional Tribunal's autonomy and jurisdiction regarding the constitutionality of laws and administrative acts, making it one of the most powerful tribunal in the world, able to stop governments' decrees and protect citizens' rights against powerful private groups. The 
armed forces' special privileges over elected politicians, in addition, were drastically cut (Bertelsmann Stiftung, 2010). ${ }^{16}$

One of the most important social reforms promoted by left governments in Chile was president Lagos’ Plan de Acceso Universal con Garantías Explícitas (Regime of Explicit Health Guarantees Plan), also labelled 'Plano AUGE' from its acronym. The plan intended to further the quality and accessibility of public sector health services, especially for the least advantaged, by supplying universal medical assistance to people meeting certain age requirements and suffering from one of a set of itemized diseases (initially 25, currently 80). In addition it established new standards for both the quality and quantity of the services provided: these constituted a specific social right to which all citizens were entitled and that the state guaranteed both legally and financially. The law also set maximum waiting times for the delivery of medical treatment and ensured that the required procedures and technologies were offered by qualified health professionals (Missoni \& Solimano 2010). This reform, finally, was supplemented by an information system and by specific analyses to evaluate compliance monitoring and impact assessment. To sum up, a series of institutions and practices were organized and reinforced, which have been customarily related to capable states.

Our claim does not imply that right governments are unable to strengthen state capacity. In the last decades, state 
capacity has increased under right governments in Colombia (see Fig. 1). While the extent of their achievements remains unclear (Feldmann, 2012), right executives helped to rebuild domestic order by curbing both political and common violence. Following Uribe's peace talks with the AUC, quite a few paramilitary leaders have been imprisoned and a dozen major commanders have been extradited to the United States: authorities initiated a demilitarization process that turned into the dissolution of an intimidating armed force. In addition, homicides have dropped from about 28,000 in 2002 to 15,000 in 2010, while tax extraction capacity has increased from 10.9 per cent of GDP in 1990 to 17.8 per cent of GDP in 2009, reaching a top of 18.2 per cent in 2006 (Gómez Sabaini \& Jiménez 2012, p. 13). ${ }^{17}$ In 2004, lastly, a civil service law ended five years of legal uncertainty, in which provisional selections affected 38 percent of personnel, introducing new merit based criteria for admission (Grindle, 2010, p. 22). In short, right governments were able to expand overall state capacity by fortifying domestic order and developing other key stateness dimensions.

\section{Conclusions}

Our investigation set up to determine the impact of democracy and political partisanship on stateness in Latin America between 1975 and 2009. We found that democracy 
does propel state capacity: while the progressive opening of political regimes contributed to lessen the negative impact of autocracies and anocracies, only democratic regimes exercised a positive bearing on stateness. In a similar manner, our hypothesis on the effects of the partisan composition of government was proven correct: only left and left leaning governments were found to have a positive and significant impact, while other executives did not show a discernible trend, except for the most conservative governments which did play a negative role. The almost perfect fit between our empirical findings and the expected outcomes greatly strengthens these conclusions, which can be enunciated not only in quantitative and relative terms, but also qualitatively with reference to the concepts of democratic regimes, on the one hand, and left and left-leaning executives on the other.

Although operating at times as self-interested actors, Latin American parties and governments pursue objectives which are valued by their electoral bases and that differentiate them and their policy positions. Through the mechanisms outlined above and following elaborate historical processes, they have come to develop policies and strategies that have a bearing on the complex course of state formation and change. Whereas not always linear or univocal, the policies developed by left and left-leaning executives appear to have strengthened stateness in the area more than the policies implemented by right and right- 
leaning governments, reflecting the organizational and ideological ties linking governments and parties to particular constituencies and organized interest groups. From a methodological standpoint our claim is that, by underlining the links between public policies and state capacity and offering an evaluation of executives' partisanship, our investigation goes beyond the analysis of formal state institutions and delves into a deeper and richer political inquiry, grounded on a political economy of state capacity that takes into account the role of social groups, such as urban labor or the middle classes, and their interactions, as reflected by the presence and workings of political parties which these groups represent and act for.

Our study adds to a new line of inquiry relating democracy, political partisanship and stateness. Although in its infancy, this path promises to shed some light on this intricate relationship, resting on the delicate balance of politics, economics and society: it does so by articulating a more complete and credible story about the ways power is shared and shaped in society and how these interactions affect the forms and contents of state capacity in contemporary Latin America. The exploration of these issues represents a propitious avenue of investigation for the years to come. 


\section{$\underline{\text { Notes }}$}

1. In this article we will use the terms state capacity, state capability and stateness as equivalent (Fukuyama, 2005).

2. A fourth more controversial dimension relates to state legitimacy, understood as the rightful exercise of power as recognized by voters. This component has often been considered instrumental to state capacity, rather than one of its essential features (Levi, 2002, p. 40). Legitimacy levels, in fact, are sometimes higher in authoritarian countries, as China or Azerbaijan, than in democratic ones, as France or New Zealand (Gilley, 2006, p. 517). Some authors, in addition, find that legitimacy rights, operationalized as broad approval of a government's rights to oblige people to pay taxes, are not related to political rights (Levi \& Sacks, 2009, p. 326). We finally excluded legitimacy from our operationalization of stateness, since introducing this dimension may lead to endogeneity problems when analyzing the democracy-stateness nexus.

3. In line with the observations above, special attention is demanded to researchers to avoid conflating the ability to administer from the services themselves and the policy choice to tax from the ability of the state collection apparatus to collect the assessed taxes.

4. We exclude other measures of democracy, for instance the Mainwaring and Brinks index (2007), as these authors use critical elements of our dependent variable, such as political order, to define the presence and strength of democracy in the area, generating endogeneity problems. These authors qualify Colombia (1980s to the present) and Peru (1980s and early 1990s) as undemocratic, given the government's and paramilitary’s campaigns against guerrillas and drug trafficking carried 
out during this period (Ibid.: 7). The measure suggested by Huber et al. (2012) conversely, is structured around four regimes types

(Authoritarian Regimes, Bureaucratic Authoritarian Regimes, Restricted Democracies and Full Democracies) which drastically restrict our analysis to two categories of democracy.

5. Relatively wealthy, enduring and sound democracies exhibit lower levels of internal conflict and are associated with lower chances to resort to political violence (Collier \& Rohner, 2008). Yet, Mansfield and Snyder (2005) argue that countries in transition to electoral politics are particularly inclined to civil war, revolution, and ethnic and sectarian hostility.

6. In most Latin American countries, political parties tend to be less established and their ideologies and electoral pledges less clearly articulated than in the industrialized West: however, experts ordered them into the same left, center-left, center, center-right, and right political spectrum, along with an additional category of personalist parties (Coppedge 1997; Huber et al. 2006, 949).

7. Scholars emphasize the presence of many "lefts" in Latin America, differentiating between a programmatic left (as in Brazil, Chile, Uruguay) and a non-programmatic left (as in Argentina and Bolivia), though they are not always explicit about this (Pribble, 2013; Levitsky \& Roberts 2013; Weyland \& Gates, 2011; and Cameron \& Hershberg 2010). This taxonomy is important, since it is sensible to assume that only a programmatic left party would invest in building state capacity. When parties are not programmatic, electors are not oriented towards programs in their voting, it is problematic to hold leaders responsible, and incumbents have no motivation to translate electoral pledges into 
effective policies. Our operationalization (Huber et al., 2012), is largely in line with this distinction.

8. We assessed the partisan orientation of government recoding the variable in the following way: 0 for left through 8 for right governments (Huber et al., 2006). This measure has been labeled "Executive Partisan Balance”.

9. In Latin America, a 14 years period corresponds roughly to three presidential terms (Martinez-Gallardo 2011, p. 13).

10. Duration refers to the uninterrupted number of years of existing democratic systems, taking 1945 as the first year in our time series.

11. Countries where oil rents are less than 10 per cent of GDP were coded 0; and countries where oil rents are superior to 10 per cent of GDP were coded 1.

12. For some, ethnic composition does not fuel violence and fragmentation automatically; it does so, only when trigger factors, such as unscrupulous leadership; opportunistic neighbors; and shattered or growing hopes detonate structural contradictions (Gurr, 1994).

13. Namely: Argentina, Bahamas, Barbados, Belize, Haiti, Jamaica and Suriname. The countries finally included are: Bolivia, Brazil, Chile, Colombia, Costa Rica, Dominican Republic, Ecuador, El Salvador, Guatemala, Guyana, Honduras, Mexico, Nicaragua, Panama, Paraguay, Peru, Trinidad and Tobago, Uruguay and Venezuela.

14. As we found some heteroskedasticity, we employed cluster-robust standard errors, which yield a consistent VCE estimator (see Arellano, 2003; Stock \& Watson, 2008; Wooldridge, 2009).

15. In their classification of political parties in the area, Coppedge (1997) and Huber et al. (2012) distinguish between secular and Christian parties. Point 7 in Figure 7 corresponds to Christian right-wing executives. 
16. During this period, tax collection grew slightly, by about 1 percent (Gómez \& Jiménez, 2012, p. 13).

17. Flores-Macias (2014) claims that security crises in Colombia provided right parties a unique window of opportunity to strengthen tax capacity, as illustrated by president Uribe's adoption, in 2002, of the so-called "war tax", which can be considered as one of Colombia's most important policy responses to the FARC challenge. 


\section{$\underline{\text { References }}$}

Acemoglu, D. and J. Robinson (2008), The Role of Institutions in Growth and Development, Commission on Growth and Development Working Paper No.10, Washington DC, World Bank.

Adserà, A., C. Boix and M. Payne (2003), Are You being Served? Political Accountability and Quality of Government, in «The Journal of Law, Economics and Organization», 19, 1, pp. 44590.

Arellano, M. (2003), Panel Data Econometrics, Oxford, Oxford University Press.

Ben-Meir, A (2006), Challenges to Democracy in the Arab and Muslim World, «Review of International Law and Politics», 6, pp. 105110.

Bäck, H. and A. Hadenius (2008), Democracy and state capacity: exploring a J-shaped relationship, «Governance», 21(1): 1-24.

Barrett, P., D. Chavez and C. Rodríguez-Garavito (eds) (2008), The Latin American Left: Utopia Reborn, London, Pluto Press.

Bates, R. H. (2008). When things fell apart: state failure in late-century Africa. Cambridge University Press.

Bertelsmann Stiftung (2010), Bertelsmann Transformation Index 2010, Politische Gestaltung im internationalen Vergleich. Gütersloh, Verlag Bertelsmann Stiftung. 
Besley, T. and T. Persson (2009), The Origins of State Capacity: Property Rights, Taxation and Politics, «American Economic Review», 99, 4, pp. 1218-44.

Bueno de Mesquita, Bruce, George W. Downs, Alastair Smith and Feryal M. Cherif. 2015. Thinking Inside the Box: A Closer Look at Democracy and Human Rights." International Studies Quarterly 49:439\{457.

Bratton, M. (2008), Do free elections foster capable government? The democracy-governance connection in Africa, Afrobarometer Working Paper, 104, 331-354.

Bresser-Pereira, L. (2001), The New Left viewed from the South, , in A. Giddens (ed.), The Global Third Way Debate, Cambridge, Polity Press.

Carbone, G. (2013). Democratisation as a State-Building Mechanism: A Preliminary Discussion of an Understudied Relationship, «Political Studies Review», (forthcoming, doi: 10.1111/14789302.12020).

Carbone, G. and V. Memoli (2015), Does democratization foster state consolidation? Democratic rule, political order and administrative capacity, «Governance», 1, pp. 5-24.

Cameron, M. A., and Hershberg, E. (Eds.). (2010). Latin America's left turns: Politics, policies, and trajectories of change (pp. 98-127). Boulder, Colorado: Lynne Rienner Publishers.

Cárdenas, Mauricio, and Didem Tuzemen (2010). "Under-Investment in State Capacity: The Role of Inequality and Political Instability." 
Cárdenas, Mauricio. "State Capacity in Latin America." Economía 10.2 (2010): 1-45

Centeno, M. (2009), El Estado en América Latina, «Revista Cidob d’Afers Internacionals», 85-86, pp. 11-31.

Charrón, N. and V. Lapuente (2010), Does democracy produce quality of government?, «European Journal of Political Research», 49, 4, pp. 443-470.

Cheibub, J. (1998), Political Regimes and the Extractive Capacity of Governments: Taxation in Democracies and Dictatorships, «World Politics», 50, 3, pp. 349-376.

Collier, P. and D. Rohner (2008), Democracy, Development and Conflict, «Journal of the European Economic Association», 6, 23, pp. 531-40.

Coppedge, M. (1997), A Classification of Latin American Political Parties, Kellogg Institute Working Paper \#244, Paris, Notre Dame.

Dahl, R. (1989), Democracy and its Critics, New Haven, Yale University Press.

Diamond, L. J. (2002). Thinking about hybrid regimes. Journal of democracy, 13(2), 21-35.

Engerman, S. L., and Sokoloff, K. L. (2002). Factor endowments, inequality, and paths of development among new world economics (No. w9259). National Bureau of Economic Research. 
Feldmann, E.A. (2012), Measuring the Colombian "Success" Story, «Revista de Ciencia Política», 3, pp. 739-52.

Flores-Macías, G.A. (2014), Financing Security Through Elite Taxation: The Case of Colombia's “Democratic Security Taxes”, «Studies in Comparative International Development», 49, 4, pp. 477-500.

Fortin, J. (2010), A tool to evaluate state capacity in post-communist countries, 1989-2006, «European Journal of Political Research», 49, 5, pp. 654-686.

Fukuyama, F. and S. Colby (2011), Half a miracle”. Foreign Policy, May/June, Available at http://www.foreignpolicy.com/articles/2011/04/25/half_a_miracl e.

Fukuyama, F. (2007), Liberalism versus State-Building, «Journal of Democracy», 18, 3, pp. 10-13.

Fukuyama, F. (2005), Stateness first, «Journal of Democracy», 16, 1, pp. 84-88

Gilley, B. (2006), The determinants of state legitimacy: Results for 72 countries, «International political science review», 27, 1, pp. 4771.

Gómez S., J. Carlos and J.P. Jiménez (2012), Tax structure and tax evasion in Latin America, Paper 118, Serie macroeconomía del desarrollo, Cepal. 
Grassi, D. (2014), Democracy, social welfare and political violence: the case of Latin America, «Journal of International Relations and Development», 17, 2, pp. 242-273.

Grassi D., and V. Memoli (Forthcoming), Democracy, Political Partisanship and State Capacity in Latin America «Italian Political Science Review».

Green, W.H. (2008), Econometric analysis (6th ed.), Upper Saddle River, New Jersey, Prentice Hall.

Grindle, M.S. (2010), Constructing, Deconstructing, and Reconstructing Career Civil Service Systems in Latin America, HKS Faculty Research Working Paper Series, RWP10-025, John F. Kennedy School of Government, Harvard University.

Grzymala-Busse, Anna. 2007. Rebuilding Leviathan: Party Competition and State Exploita-

tion in Post-communist Democracies. New York, NY: Cambridge University Press.

Gurr, T.R. (1994), Peoples against states: Ethnopolitical conflict and the changing world system: 1994 presidential address, «International Studies Quarterly», 38, pp. 347-377.

Gutiérrez, F. (2011), Evaluating state performance: a critical view of state failure and fragility indexes, «European Journal of Development Research», 23, 1, pp. 20-42.

Haggard, S. and R.R. Kaufman (2008), Development, Democracy and Welfare States, Princeton, Princeton University Press. 
Hagopian, F., and S. Mainwaring (2005), The Third Wave of Democratization in Latin America: Advances and Setbacks, Cambridge, Cambridge University Press.

Hanson, J.K. and R. Sigman (2013), Leviathan's Latent Dimensions: Measuring State Capacity for Comparative Political Research, Manuscript, Maxwell School of Citizenship and Public Affairs, Syracuse University.

Hendrix, C. (2010), Measuring state capacity: theoretical and empirical implications for the study of civil conflict, «Journal of Peace Research», 47, 3, pp. 273-285.

Herbst, J. and G. Mills (2006), Africa's big dysfunctional states : an introductory overview, in C. Clapham, J. Herbst and G. Mills (eds), Big African states. Johannesburg, Wits University Press.

Huber, E. and J.D. Stephens (2012), Democracy and the Left: Social Policy and Inequality in Latin America, Chicago, University of Chicago Press.

Huber, E., J. Stephens, J., T. Mustillo and J. Pribble (2012), Latin America and the Caribbean Political Dataset, 1945-2008, Available at http://www.unc.edu/ jdsteph/documents/common/data/Codeboo k_LAC_Political_2012.doc.

Huber, E., F. Nielsen, J. Pribble and J.D. Stephens (2006), Politics and Inequality in Latin America and the Caribbean, «American Sociological Review», 71, 6, pp. 943-63. 
Huber, Evelyne, and John D. Stephens (2001). Development and crisis of the welfare state: parties and policies in global markets. Chicago: University of Chicago Press.

Karl, T. (2004), Encyclopedia of Energy, Vol. 4. R., Elsevier Inc.

Levitsky, S., and Roberts, K. M. (Eds.). (2013). The resurgence of the Latin American left. JHU Press.

Levitsky, S. and L. Way (2002), The Rise of Competitive Authoritarianism, «Journal of Democracy», 13, 2, pp. 51-65.

Levi, M. (2002), The State of the Study of the State, in I. Katznelson and H. Milner (eds), Political Science: The State of the Discipline, London, APSA/Norton, pp. 33-55.

Levi, M. and A. Sacks (2009), Legitimating Beliefs: Sources and Indicators, «Regulation \& Governance», 3, 4, pp. 311-33.

Mainwaring, S., Brinks, D. M., \& Pérez-Liñán, A. (2007). Classifying political regimes in Latin America, 1945-2004.

Mann, M. (2008), Infrastructural power revisited, «Studies in Comparative International Development», 43, 3-4, pp. 355-365.

Mansfield, E. and J. Snyder (2005), Electing to Fight: Why Emerging Democracies Go to War, Cambridge, MIT Press.

Marshall, Monty G.; Cole, Benjamin R.(2014) "Global Report 2014 Conflict, Governance, and State Fragility" July 23.

Martinez-Gallardo, C. (2011), Designing cabinets: presidential politics and cabinet instability in Latin America, Kellogg Institute Working Paper 375, University of Notre Dame. 
Mata, J. F. and S. Ziaja (2009), Users' Guide on Measuring Fragility, German Development Inst..

Merkel, W. (2001), Embedded and Defective Democracies, Paper presented at the Meeting of the American Political Science Association, Washington, D.C.

Missoni, E. and G. Solimano (2010), Towards universal health coverage: the Chilean experience. World health report, Background Paper, 4, World Health Organization, Switzerland, Geneva.

Nelson J. (2007), Elections, Democracy and Social Services, in Studies in Comparative Development, 41, 4: 79-97.

O’Donnell, G. (1993), On the State, Democratization, and Some Conceptual Problems: A Latin American View with Some Glances at Post-Communist Countries, «World Development», 21, 8, pp. 1355-69.

Pellegrini, L., and R. Gerlagh (2008), Causes of corruption: a survey of cross-country analyses and extended results, «Economics of Governance», 9, pp. 245-63.

Pribble, J. (2013). Welfare and party politics in Latin America. Cambridge University Press.

Rangel, A. (2005), Sostenibilidad de la Seguridad Democrática, Bogotá, Fundación seguridad y democracia.

Rauch, J.E. and P.B. Evans (2000), Bureaucratic structure and bureaucratic performance in less developed countries, «Journal of public economics», 75, 1, pp. 49-71. 
Saylor, R. (2012), Sources of state capacity in Latin America: commodity booms and state building motives in Chile, «Theory and society», 41, 3, pp. 301-324.

Schumacher, G. and B. Vis (2009), Party Organization, Electoral Competition and Reform of Welfare State Generosity in OECD Countries, 1973-2002, Paper Prepared for the Annual Meeting of the APSA, Toronto, September 3-6.

Sikkink, K. (1991), Ideas and Institutions: Developmentalism in Brazil and Argentina, Ithaca, Cornell University Press.

Slater, D. (2008), Can Leviathan be democratic? Competitive elections, robust mass politics and state infrastructural power, «Studies in Comparative International Development», 43, pp. 252-272.

Sojo, C. (2011), The State under scrutiny: Public opinion, Stateness and government performance in Latin America, Santiago de Chile, Cepal.

Soifer, H.D. (2012), Measuring State Capacity in Contemporary Latin America, «Revista de Ciencia Política», 32, 3, pp. 585-98.

Stock, J. and M. Watson (2008), Heteroskedasticity-robust standard errors for fixed effects panel data regression, «Econometrica», 76, pp. $155-174$.

Svolik, Milan W. 2012. The Politics of Authoritarian Rule. New York, YU: Cambridge

University Press.

Weber Max (1978) Economy and Society. Berkely: University of California Press. 
Weyland, K., and Gates, L. C. (2011). Electing Chávez: The Business of Anti-Neoliberal Politics in Venezuela. Perspectives on Politics, 9(2), 464.

Zakaria. F. (1997), The Rise of Illiberal Democracy, «Foreign Affairs», 76, 6, pp. 22-43.

Wang, Erik Haixiao, and Yiqing Xu. "Awakening Leviathan: The Effect of Democratization on State Capacity, 1960-2009." Available at SSRN 2626849 (2015).

Wooldridge, J. (2009), Introductory Econometrics: A Modern Approach, 4th ed., Cincinnati, Ohio, South-Western. 
Table. 1 The effect of democracy and partisanship on Stateness in Latin American

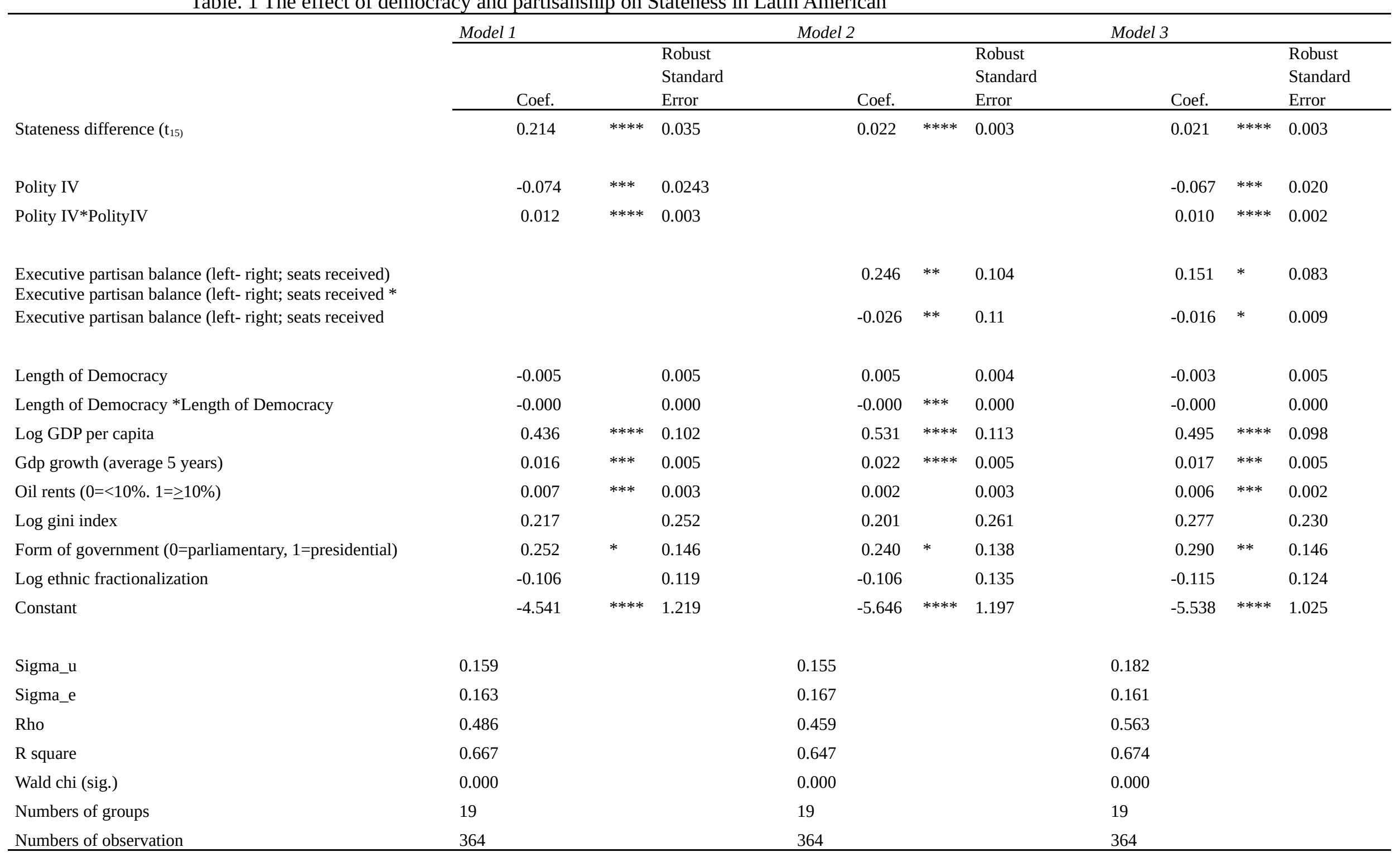

Note: ${ }^{*} \mathrm{p}<0.10 ;{ }^{* *} \mathrm{p}<0.05 ;{ }^{* * *} \mathrm{p}<0.01 ; * * * * \mathrm{p}<0.001$. We have applied a random-effects GLS regression. 
Figure 1

Changes in stateness in Latin America (1960-2009)

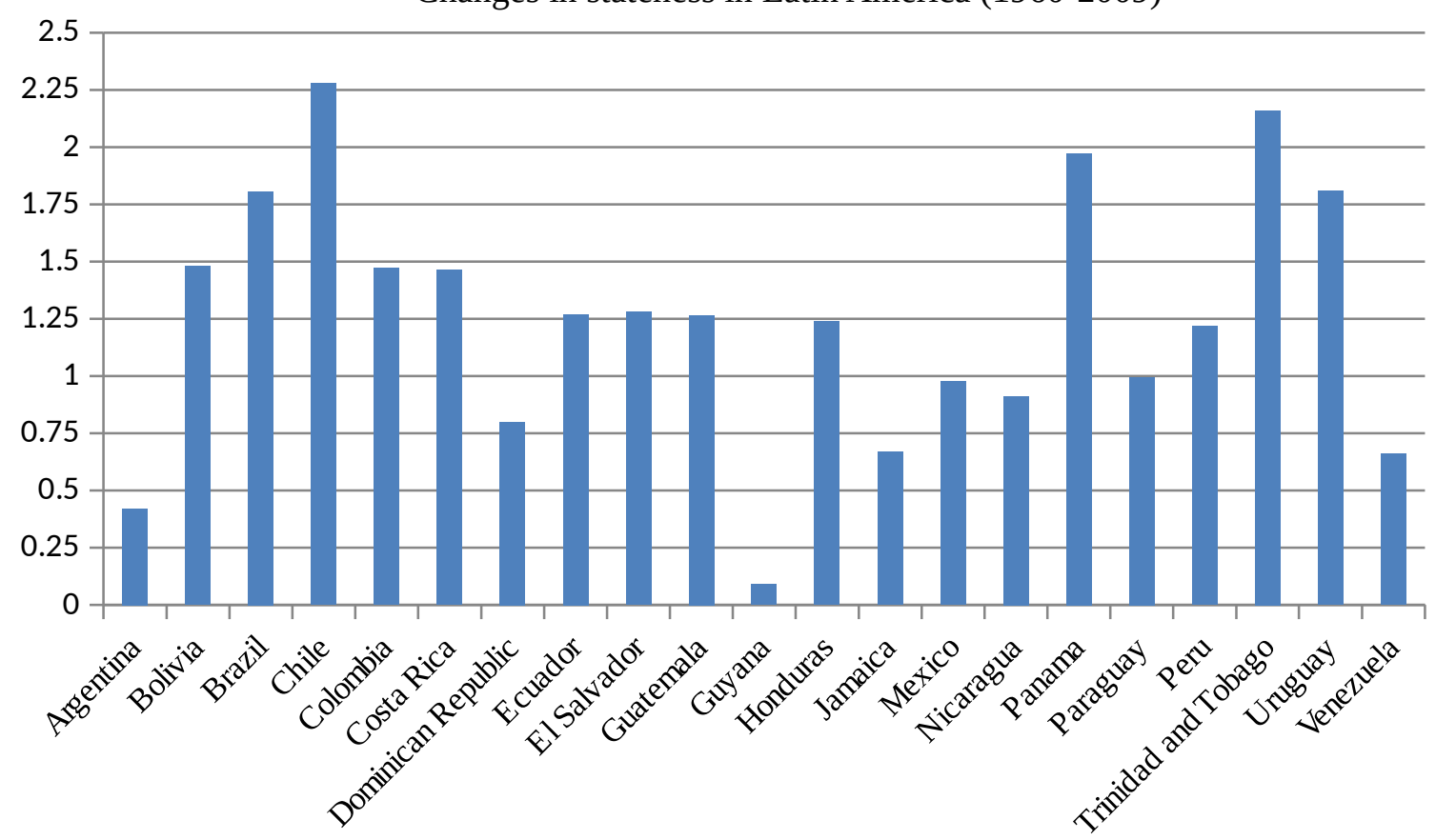

Source: Hanson and Sigman (2013).

Figure 2

Changes in stateness in Chile (1960-2009)

Chile

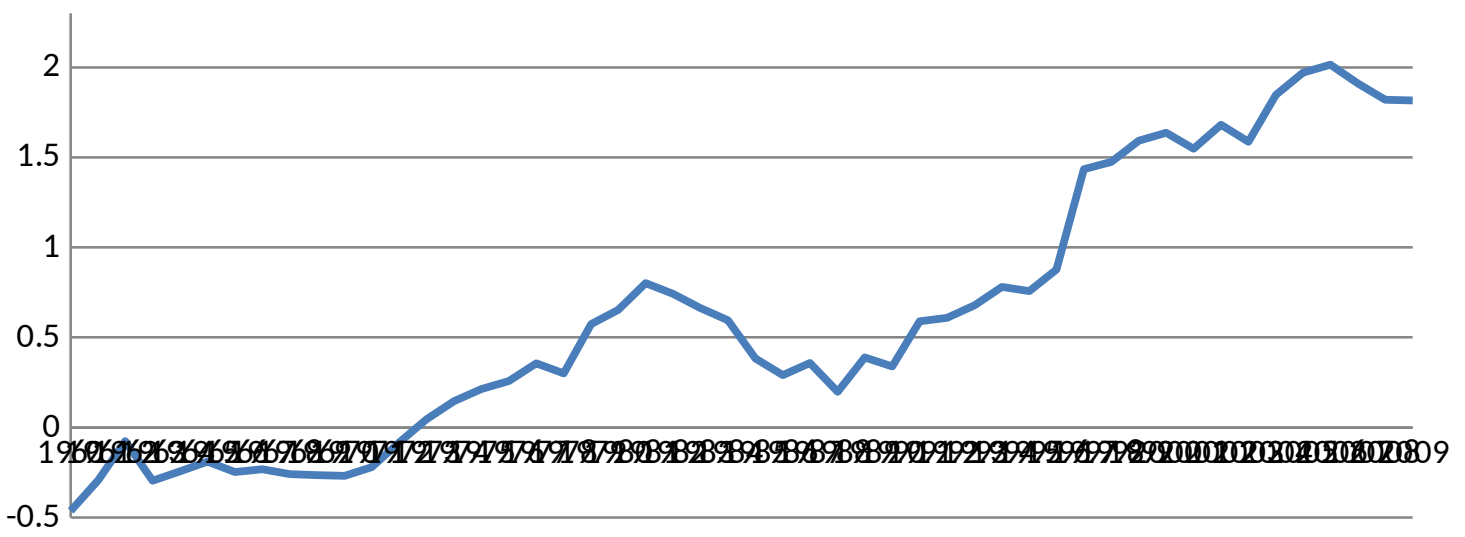

Source: Hanson and Sigman (2013). 
Figure 3

Changes in stateness in Uruguay (1960-2009)

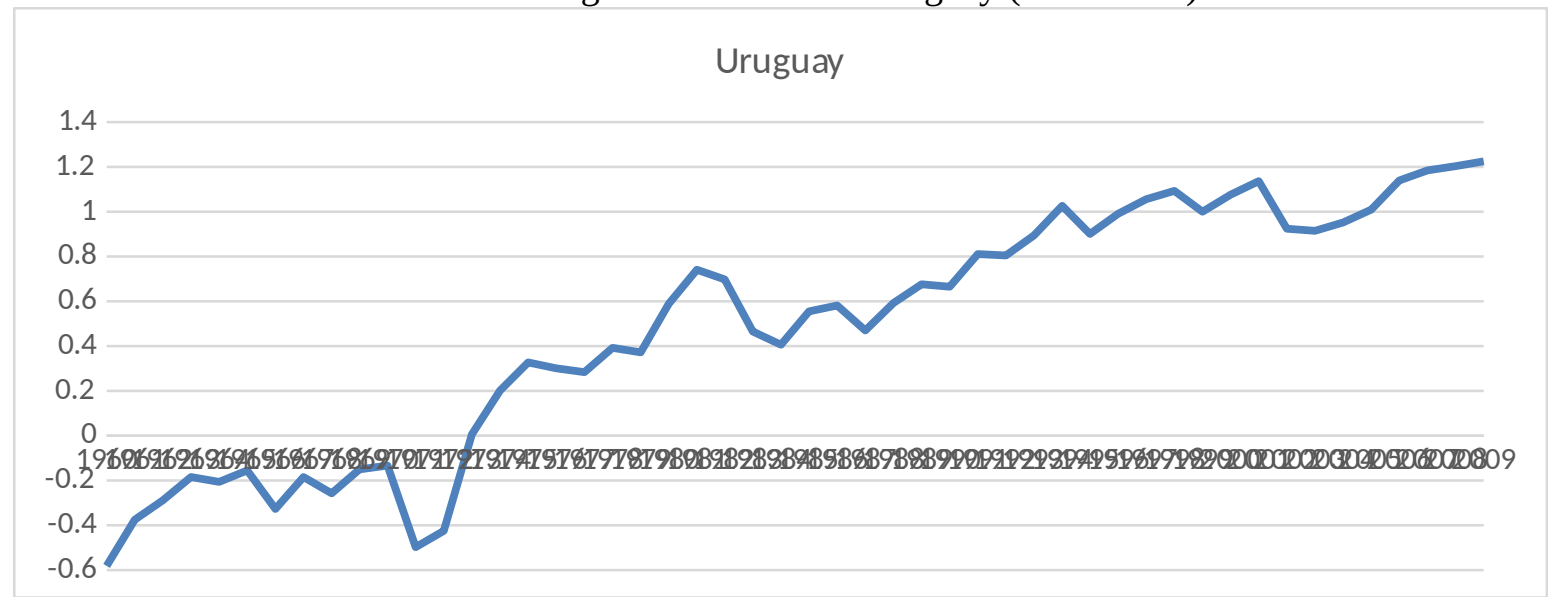

Source: Hanson and Sigman (2013).

Figure 4

Changes in stateness in Paraguay (1960-2009)

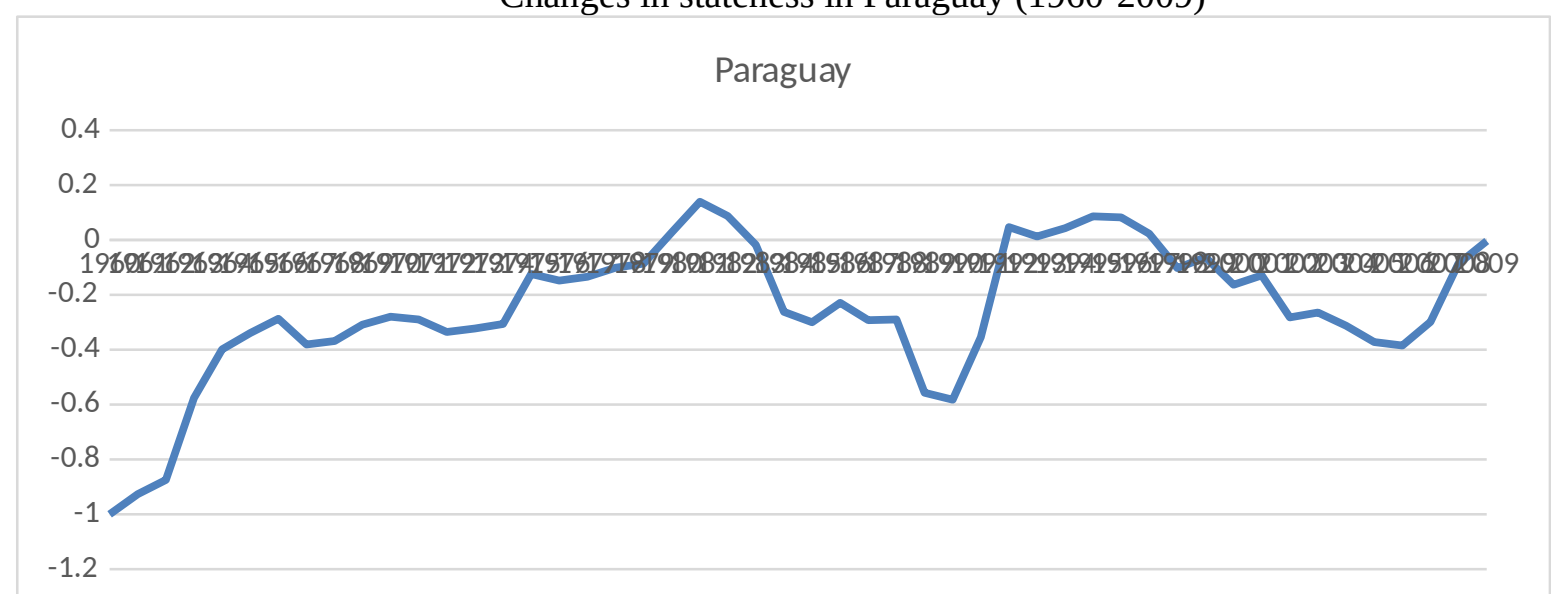

Source: Hanson and Sigman (2013).

Figure 5

Changes in stateness in Venezuela (1960-2009)

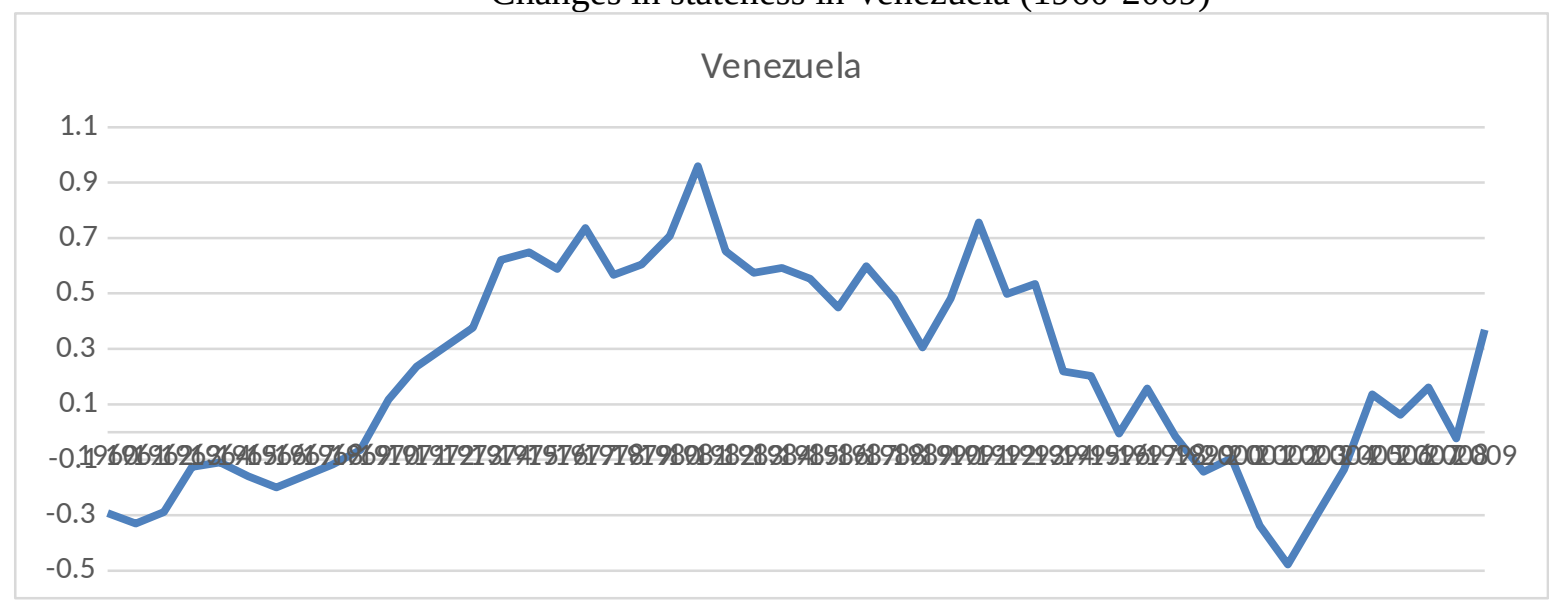

Source: Hanson and Sigman (2013). 
Figure 6

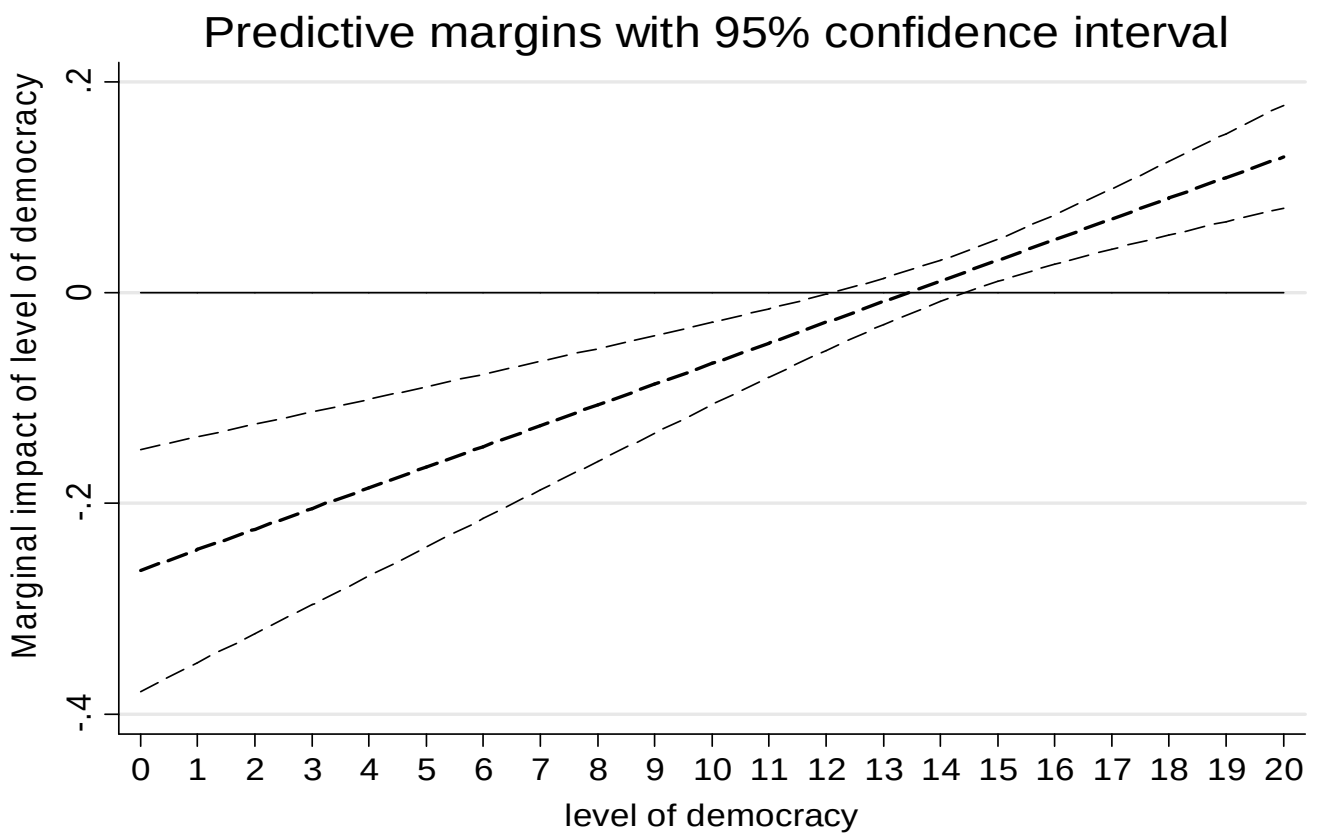

Figure 7

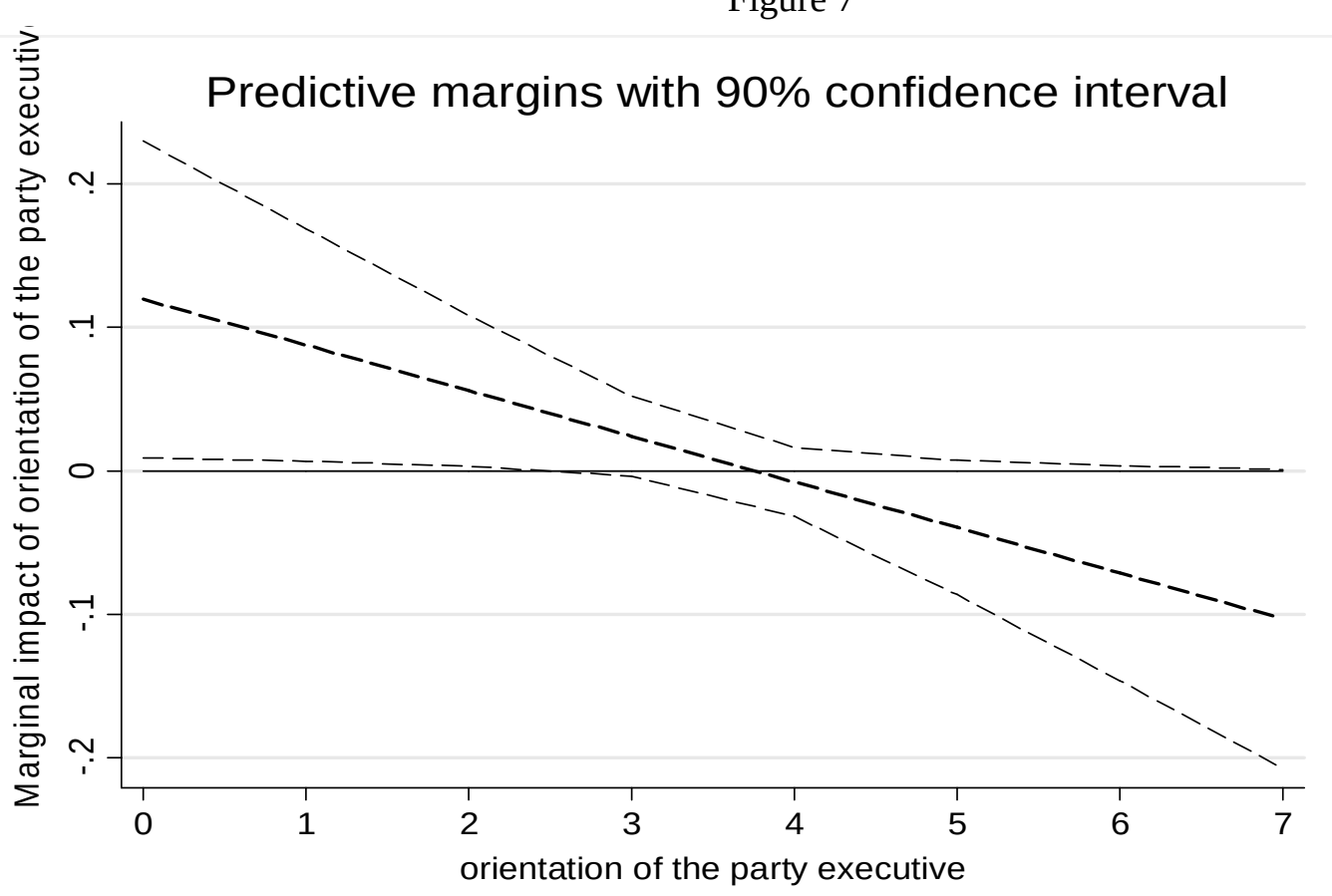


Dear Editors,

The authors certify that they have NO affiliations with or involvement in any organization or entity with any financial interest (such as honoraria; educational grants; participation in speakers' bureaus; membership, employment, consultancies, stock ownership, or other equity interest; and expert testimony or patent-licensing arrangements), or non-financial interest (such as personal or professional relationships, affiliations, knowledge or beliefs) in the subject matter or materials discussed in this manuscript.

In faith, Davide Grassi and Vincenzo Memoli 


\section{Political Determinants of State Capacity in Latin America}

Davide Grassi Università degli studi di Torino

Vincenzo Memoli Università degli studi di Catania

Abstract:

In this article, we argue that both democracy and governments' partisanship have had a bearing on state capacity in Latin America. We also maintain that state capacity is a condition rooted in history and society: it can be built or purposefully undermined. In particular, in Latin America parties of the left have frequently operated to reallocate social and political clout in favor of underprivileged groups: the inclusion of the latter in the political process helped states to thwart pressures from dominant elites opposing redistribution and tax increases. These mobilized groups have also pushed for universal public services, as high-quality education, health care or public housing, which required well-functioning administrations and an adequate institutional capacity, thus contributing to consolidate stateness in the area. Whereas previous qualitative studies analyzed the mechanisms that relate democracy and political partisanship to state capacity, we test this hypothesis quantitatively. To this end, we estimate the effect over time of democracy, political parties and other socio-demographic factors on a composite measure of stateness, obtaining supportive evidence: in particular, we find that higher democracy levels and left-leaning governments favored the growth of 
state strength in the area between 1975 and 2009 and discuss these findings with reference to the political experience of Latin America. 
In this article we argue that both democracy and governments' partisanship have a bearing on state capacity in Latin America: in particular, we find that higher democracy levels and left-leaning governments favored the growth of state strength in the area between 1975 and 2009. Whereas previous qualitative studies have analyzed the mechanisms that relate democracy and political partisanship to state capacity, we test this hypothesis quantitatively, obtaining supportive evidence. Our work is organized as follows: in the next section, we discuss the relevant literature, then define our main dependent, independent and control variables, paying special attention to the thorny concept of state capacity. Subsequently, we submit our main hypotheses and summarize the mechanisms at work. Finally, we estimate the effect over time of democracy, political parties and other socio-demographic factors on a composite measure of stateness; discuss these findings with reference to the political experience of Latin America; and underline our contribution to the ongoing debate. Conclusions, as usual, wind up the analysis.

Social science literature has mostly considered democracy and stateness as causally independent or it has taken the latter to be a precondition for the former (Wang \& Xu, 2015). The rare works analyzing the bearing of democracy on state capacity generally underscore a positive association: the superior political accountability of democracy lowers corruption and the risk of property expropriation and strengthens bureaucratic quality and the rule of law, thus improving overall state capacity (Adserà et al., 2003). As a result of vigorous political competition, for instance, various non-partisan state 
organs and policy reforms aimed at increasing government efficiency were implemented in Hungary, Lithuania, Poland and Slovenia after their democratic transitions (Grzymala-Busse, 2007). In Africa, as well, democracy has been empirically associated to several components of state capacity as rule of law, effectiveness, accountability and control of corruption (Bratton, 2008). In Malaysia, Indonesia and the Philippines, competitive elections have facilitated state-building by stimulating the formation of stronger political parties; a more vigorous state commitment to voters' registration; and the imposition of centralized authority over societal strongmen (Slater, 2008). In short, the historical influence of parliamentary democracy has been considered to be an unusually stable predictor of both the legal and fiscal capacities of the state (Besley \& Persson, 2009): democracy strengthens stateness by enhancing government responsiveness to citizens; by facilitating the diffusion of information between policy-makers and voters (Bueno de Mesquita et al., 2015); and by increasing political contestation (Wang \& Xu, 2015).

The influence of democracy, however, is still controversial as strong developmental states have existed under authoritarian regimes in Asia (for instance in Taiwan and South Korea). In addition, the assertion that democracy strengthens the consolidation of state institutions must confront the sensible objection that democracy can subsist only after a minimally functional state is already in place (Carbone \& Memoli, 2015). Thus, analyzing African regimes in the early 1990s, Bates (2008) claims that electoral competition and state failure go together since, during democratic openings, incumbents are 
less secure about their tenure and rewards from predation multiply, encouraging domestic conflicts and state collapse. In new democracies, in addition, objectionable politicians might emerge who view the new democratic politics as a "one-time opportunity to get rich" (Svolik, 2012). Others, finally, point at a non-linear relationship: Charrón and Lapuente (2010) claim that deprived countries enjoy higher 'administrative capacity' under despotic rule, while richer countries perform better under democracy. Bäck and Hadenius (2008) similarly contend that the association between level of democratization and 'administrative capacity' is negative at low levels of democratization, but positive at higher levels. Administrative capacity declines initially as the political system opens and a plurality of social and political actors undermine authoritarian controls from above: however, as mature and more stabilized democratic regimes develop, bottom-up mechanisms of policy control emerge that help attain the highest levels of administrative capacity.

In Latin America, democracy has not been typically studied as a determinant of state capacity, but rather as one of its outcomes: thus, poor democratic conditions are often explained as a consequence of local states weakness. Accordingly, among the key determinants of state capacity scholars mention particular historical heritages; features such as the amount of trust in public and private institutions; economic and social inequalities; and globalization (Centeno, 2009). Cárdenas, however, singles out political inequality as one of the factors that possibly account for the extraordinarily low state capacity in the region, in conjunction with economic inequality, regional 
struggles, and civil war (2010). Others maintain that democratic rule strengthens the capacity of the state to provide citizens with fundamental social services, by encouraging politicians to reach the poor and those more exposed to risk, and these latter to organize (Haggard \& Kaufmann, 2008).

Whether and how in Latin America state capacity has been shaped by democratic rule, however, remains an open question. Acemoglu and Robinson (2008), for instance, notice that the trend toward greater democracy in the area has not been accompanied by a similar change in state capacity, which has remained especially low. They argue that, even if de jure democratic institutions have been established (political rights, voting and checks on the executive), the political balance has not changed for the presence of crucial de facto powers, as dominant social groups. Likewise, Cheibub (1998) underlines that, from 1970 to 1990, governments' extractive capacity has not been much stronger in democracies than in authoritarian regimes. Grassi and Memoli (forthcoming), finally, find that between 1995 and 2009 democracy has weakened the negative effects of autocracy on state capacity, but it has been insufficient, by itself, to promote its strengthening. There are, in short, several objections to the view that democracy always advances stateness: antagonistic electoral competition can undermine a state and democratic petitions may overburden and deteriorate political institutions (Hagopian \& Mainwaring, 2005). Rather than contributing to reinforce state institutions and increase their effectiveness, therefore, the acceptance 
of formally democratic institutions may actually corrode or disintegrate state authority and public services.

State capacity, on the other hand, is a condition rooted in history and society: it can be built or purposefully undermined (Grassi \& Memoli, forthcoming). In most instances, states that achieved vigorous stateness in time did not have the necessary ability nor the right bureaucracies to do so in the beginning: where a political leadership committed to growth and equality had reached a settlement with domestic actors to define a common policy framework, a developmental and welfare- improving bureaucracy was typically created to support it (Haggard \& Kaufmann 2008). In other cases, a weaker state capacity (the limited power to levy taxes, for instance) was the result of the veto power exercised by powerful social groups that successfully resisted increases in the tax load (Huber \& Stephens 2012, 41). Parties of the left generally operate to reallocate social and political clout in favor of underprivileged groups: the inclusion of the latter in the political process helps states to thwart pressures from dominant elites opposing redistribution and tax increases. These mobilized groups push for administratively challenging universal public services, as high-quality education, health care or public housing, and the institutional capacity necessary to provide them, thus contributing to consolidate stateness. Parties of the right, in turn, often advocate order and legality, since crime and violence jeopardize business investments and growth and are usually aimed at affluent individuals. A stronger state, in addition, allows for an effective enforcement of property rights, duly supported by smoothly 
functioning legal institutions, and contributes to restrain widespread corruption. Where established safeguards of this kind are absent, insecurity and unpredictability arise, which endanger new investments, the creation of jobs and the development of business (Fukuyama, 2007).

Finally, electoral competition crucially interacts with ideological preference. When election results are uncertain, regardless of ideological orientation, parties may be driven to embark on policies that they might otherwise ignore, for the sole purpose of gaining or retaining power (Haggard \& Kaufman 2008, 360). Policies may be endorsed to capture the independent voter at the center and will be more moderate, or reformist, than the ideological position of each party implies. Consequently, left-wing and right-wing executives may become more similar: the former cannot support their favorite policy of welfare state extension because of budget limitations; the latter cannot adopt their favorite policy of cutbacks because their constituencies have become attached to welfare state programs (Schumacher \& Vis 2009). To sum up, the contribution of political partisanship to the construction of state capacity in Latin America is a question that demands an empirical answer.

\section{State Capacity}

State capacity is a thorny concept, arduous to define and operationalize: in fact, there is greater scholarly agreement on key features of the state than on how to operationalize such features or the 
concept of the state itself (Carbone, 2013, 6). In the last few years, however, political scientists and sociologists have engaged in an extensive and critical debate: while failing to yield a common position, the ongoing discussion suggests points of convergence (see the special issues of Studies in Comparative International Development, 2008; and Revista de Ciencia Política, 2012). ${ }^{1}$ Definitions of state capacity often rest on the ability of state institutions to effectively implement official goals (Sikkink, 1991). This approach solves a first significant problem, namely the normative definition of what the state ought to do or how it ought to do it, and underlines the fact that capable states may organize the economy and society in different ways. Thus, in the aftermath of the neoliberal cutbacks in state intervention and bureaucracy in Latin America, one should be able to avoid confounding minimal but capable states as Chile with essentially weaker states. A second recurring theme has to do with Mann's “infrastructural power" concept, that is "the institutional capacity of a central state, despotic or not, to penetrate its territories and logistically implement decisions” (2008). Mann's contribution underlines "the question of the state's authority over territory" and "whether governments can implement policies, including the provision of public goods” (Fortin, 2010, 656). In short, the infrastructural power of the state may be read as the ability to translate policy choices into outcomes. In addition, many authors also typically indicate state capacity through at least one of three constituent elements: the ability of a state to impose a degree of internal political order, by way of an exclusive control over the means 
of coercion; the proper workings of a basic administrative apparatus; and the capacity to extract revenue from its citizens. ${ }^{2}$

Weber famously defined the state in terms of its coercive capacity, based on the monopoly of the legitimate use of physical force within its territory (Weber, 1978). Imposing political order requires a state to secure its frontiers, defend domestic order and apply laws and policies by restraining violence, i.e. to control the territory by both suppressing and preventing internal conflict and defending the borders from external invasion. A basic administrative apparatus is working properly when a professional and insulated bureaucracy is able to plan and develop policies and deliver public goods and services, which implies technical skills, competent civil servants, limited public corruption, and an effective influence across state territory. Extractive capacity, finally, indicates the ability of the state to extract resources from society, mainly in the form of tax and implies a series of critical competences and skills: instruments to access population; means to assemble and organize complex information; the possibility to count on law-abiding civil servants; and ways of assuring popular compliance with tax policies (Hanson and Sigman, 2013, 4). ${ }^{3}$

The operationalization of state capacity has also been controversial, but some points of convergence are also discernible. Most agree that any single variable is unlikely to adequately capture its multidimensional nature (Hendrix, 2010, 283). Composite indexes of the concept should also avoid incorporating potential causes, as lack of democracy, or expected consequences, as humanitarian 
disasters (Gutiérrez, 2011; Mata \& Ziaja, 2009; Soifer, 2012). Finally, the ideal data should be based on time-series cross-national measurements of stateness that ensure wide-ranging geographic and temporal coverage, enabling researchers to take advantage of variations across space and time. Based on these reflections, we decided to use the State Capacity Dataset (1960-2010) elaborated by Jonathan Hanson and Rachel Sigman (2013), which covers up to 174 countries for the period 1960-2010. The dataset rests on the three main components examined above: coercive, administrative and extractive capacities, which are measured in turn by 24 main indicators. By way of latent variable analysis, finally, the authors identify a series of underlying factors that signify overall state capacity.

More precisely, coercive capacity is indicated by four sets of data, beginning with military personnel and expenditures. Yet, a sizeable military force may signify war or domestic insecurity, both of which lessen state capacity. Consequently additional data has been added, as the extent to which the state has a monopoly on the use of force; is directly involved in committing violence; or is present in the territory, by looking for instance at the extent to which land is mountainous and therefore arduous to reach. Administrative capacity is evaluated also based on four groups of data: the ICRG (International Country Risk Guide) Bureaucratic Quality Index; an assessment of census frequency, which denotes both the capacity to gather data and effective territorial control; measurements of contract intensive money, which stand for the state capacity to police economic exchange; and an additional series of indexes related to administrative 
capacity and civil service value, such as the Weberianness Index elaborated by Rauch and Evans (2000). Extractive capacity, finally, is initially measured by tax revenues as a percentage of GDP. In order to distinguish between policy choices and extractive capacity, however, additional measures were added, as the ratio of tax revenues originating from income, domestic consumption and property taxes relative to revenue coming from international trade, as custom duties. The higher the proportion of the former, which require a more structured bureaucratic apparatus, the greater is the expected level of extractive (and administrative) capacity of the state. Other indicators, finally, show the link between actual revenue collection and the expected tax yield, given GDP per capita, mineral production, exports and additional relevant factors.

\section{Independent and control variables}

We decided to use a minimalist notion of democracy to avoid merging attributes of political authority and state qualities (as capacity), since our objective is to disentangle this relationship. Our procedural definition is based on universal suffrage; free, transparent and competitive elections; and the defense of crucial civil and political rights (along with the presence of alternative sources of information). Formal democratic institutions must also be sovereign (Dahl, 1989). Consequently, democracies do not comprise hybrid or 'electoral authoritarian' regimes, since these do not convene free and fair elections, an essential requirement of this type of government 
(Diamond, 2002; Levitsky \& Way, 2002). Democracies, finally, may also be imperfect and incomplete: 'defective' democracies only partially safeguard political rights (Merkel 2001); 'illiberal' democracies inadequately protect civil rights and the rule of law (Zakaria, 1997); and 'delegative' democracies are insufficiently responsive to citizen choices, poorly constrained by government agencies and not respectful of the rule of law (O'Donnell, 1994). To measure democracy, we resorted to the Polity IV data, on a scale that runs from -10 (full autocracy) to +10 (full democracy): the curators of the Polity IV dataset distinguish among 'autocratic regimes'; 'anocracies’; and 'democracies'. 'Anocracy' is a term used to describe a regime type that is characterized by inherent qualities of political instability and ineffectiveness, as well as an "incoherent mix of democratic and autocratic traits and practices." (Marshall \& Cole, 2014). These regimes are further differentiated among 'closed' and 'open' varieties: the former are characterized by Polity IV values comprised between -5 and 0 ; the latter by values ranging from 1 to 5 . Values of 6, or larger, denote democratic regimes, while values included between -10 and -6 identify autocratic regimes. ${ }^{4}$

Democracy impacts stateness by reducing violence and corruption and increasing administrative efficacy. It lowers violent conflict by offering institutionalized communication channels with political adversaries, by incorporating them into the debate and by yielding to some of their petitions. ${ }^{5}$ By making the government accountable, citizens are more likely to identify with democracy and the state and have fewer reasons for violent opposition. Independent 
civil society groups monitor and assess state functioning and cooperate with the state to recommend new policy ideas. Finally, by making elected officials and administrators responsible, democratic processes and sanctions restrain incompetence, arbitrariness and the diffusion of bribery (Carbone, 2013). We do not rule out, however, that the relationship between democracy and stateness may assume a non-linear form: as recalled above (Bäck \& Hadenius, 2008), different political regimes may have a diverse impact on stateness.

We classified Latin American parties based on a left/center-left versus right/center-right dichotomy, as in the more industrialized countries, following the categorization suggested by Coppedge (1997; Huber et al., 2012 for an update). ${ }^{6}$ Coppedge made use of experts who classified parties, along this dimension, into left; center-left; center; center-right; right; and personalist. Accordingly, parties of the right (for instance, Brazilian ARENA) attracted the successors of nineteenth century traditional elites; fascists and neo-fascists; and the conservative military (Coppedge, 1997, 8). Center-right parties (Argentine UCD) "targeted middle- or lower-class voters in addition to elite voters, by stressing cooperation with the private sector, public order, clean government, morality, or the priority of growth over distribution” (Ibid.). Coppedge classified as centrist (Argentine UCR) parties that "stressed classic political liberalism, the rule of law, human rights, or democracy, without a salient social or economic agenda”. Among them are "governing parties whose policies are so divided between positions both to the left and to the right of center that no orientation that is mostly consistent between elections is 
discernible” (Ibid.). Changing partisan orientation, center-left parties (Venezuelan Acción Democrática) "stress justice, equality, social mobility, or the complementarity of distribution and accumulation in a way intended not to alienate middle or upper-class voters” (Coppedge, 1997, 9). Left parties (Partido Socialista de Chile; Communist parties) "employ Marxist ideology or rhetoric and stress the priority of distribution over accumulation and/or the exploitation of the working class by capitalists and imperialists and advocate a strong role for the state to correct social and economic injustices”. (Ibid.: 10). ${ }^{7}$ Finally, parties are catalogued as personalist (Peruvian Cambio 90 or Bolivian Movimiento al Socialismo) if they "base their primary appeal on the charisma, authority, or efficacy of their leader rather than on any principles or platforms, which are too vague or inconsistent to permit a plausible classification of the party in any other way" (Ibid.). We use a continuous variable to measure the partisan orientation of governments (Executive Partisan Balance, EPB) during democratic periods. ${ }^{8}$ When the values of EPB increase, the ideological leaning of the Executive moves right (Huber et al. 2012). We also account for the fact that state capacity needs time in order to change.

Scholars' opinions (and the available evidence) on the role of partisanship in shaping state capacity are mixed. Incumbency of left parties is central for welfare state development according to comparative historical evidence (Huber \& Stephens 2012). More recently, in line with their major political objectives, Left governments have made efforts towards extending democracy and citizens’ rights, restoring state capacity, freeing while regulating markets, and building 
a satisfactory technical and political environment for skilled policymaking (Bresser-Pereira, 2001). Other investigations link vigorous mass mobilization and left-party rule to the progress of infrastructurally accomplished welfare states. However, alternative studies point at the consolidation of state capacity under right-leaning executives (Fukuyama \& Colby, 2011; Rangel, 2005) or to a process of ideological convergence by major political parties and governments that blurs partisan and policy differences (Haggard \& Kaufmann, 2008). As a result, we leave an initial answer to this issue to our empirical analysis.

Our model is completed by a number of control variables. To start with, we suggest that past levels of state capacity have a bearing on current stateness levels. It has been argued (and extensively recognized) that state capacity is path dependent and varies slowly: critical junctures in the past place institutional arrangements on paths or trajectories, which are then very difficult to alter (Centeno, 2009; Soifer, 2012). Actual degrees of state strength are therefore strongly affected by previous ones: consequently, we added a stateness difference variable calculated on stateness values prevailing 15 years earlier. ${ }^{9}$ We also added political controls: democratic duration and presidentialism. We believe that democratic duration is associated with stateness, since time allows democratic institutions and practices to get established and to take root; is necessary for democratic norms to develop and have an impact; and may encourage more participation and influence for deprived groups not only through parties, but also through the development of civil society and nongovernmental 
organisations (Nelson, 2007, 89), all of which aid the completion of state consolidation. ${ }^{10}$ Presidentialism, on the other hand, is usually thought of as a direct and effective way to govern and a weaker form of veto power in the political process, compared to parliamentarism (Huber \& Stephens, 2001, 55). Since we expect political systems characterized by stronger veto points in the policy process to slow down the expansion of stateness during the period of observation, we believe that presidentalism should have the opposite effect.

In order to test a possible spurious relationship between our main variables we also incorporate levels and growth of economic development: in fact, both state capacity and democratic governments might be the upshot of economic development over time. A host of authors argue in favor of an independent effect of economic development on state capacity. Pellegrini and Gerlagh vindicate that wealth fosters state capacity, since richer countries may afford better institutions and administrative structures and many factors associated with affluence, as levels of urbanization or schooling, lessen the social acceptance of corruption (2008, 250). Saylor contends that the quest for private profit is a potent state building cause: when pursuing profit during booms, export-oriented actors repeatedly strive for new statesupplied public goods, whose delivery encourages the expansion of state capacity (2012). Inequality is one of the major problems faced by the Latin American subcontinent: while poverty has been alleviated in recent years, inequality has proven more difficult to overcome. Higher inequality has been associated with lower stateness: historians Engerman and Sokoloff contend that inequality has been detrimental 
to the emergence of legal and fiscal capacity in Latin America (2002).

Cárdenas and Tuzemen also find that higher levels of income inequality lead to lower investments in state capacity (2010, 1-45).

Large oil rents (whenever both the state and democracy are not yet solid) deteriorate state capacity because they exempt the state from establishing an efficient tax collection system. Thus, in these countries, governments tend to be unaccountable to the general population and people, in turn, are less likely to demand accountability and political representation. Oil wealth, in addition, fuels patronage, which dilute demands for representation and accountability (Karl, 2004). ${ }^{11}$ Where ethnic fractionalization is high, elected governments must strike a balance between insertion of minority groups and protection of governing effectiveness (Ben-Meir, 2006); citizens have usually lower confidence in political institutions; and democracy is less likely to become established (Sojo, 2011). Accordingly, it is reasonable to link high fractionalization to lower stateness. ${ }^{12}$ Larger territories, finally, may also prove challenging to govern, since (ceteris paribus) vertical integration and horizontal coordination become more demanding (Herbst \& Mills, 2006).

\section{Data, methods, findings' illustration and discussion}

We chose Latin America to ensure comparability within a most similar research design: the subcontinent, in addition, represents an ideal testing ground for our main hypotheses, the bearing of political dimensions on state strength. In this area, democracies are plentiful 
and differ in quality (unlike, for instance, the Middle East), while local parties' ideologies may be sorted along a right-to-left continuum which meaningfully structures politics and political struggle (as opposed, for instance, to the political beliefs of most African and Asian parties). Political views that cause stable and intelligible policy choices, in fact, even if less easily discernible than in the developed West, are crucial for an enquiry on the potential connections between political parties acting in a democracy, partisanship and state capacity, and justifies the choice of the subcontinent to assess our research questions.

Our analysis embraces all Latin American countries, observed between 1960 and 2009: we originally considered 26 countries in total, 14 belonging to Central America and 12 to South America. Missing data problems forced us to exclude seven of them from our final report. ${ }^{13}$ Our analysis is based on a pooled cross-sectional timeseries. The advantage of longitudinal panel information, compared to cross sectional information, consists in its potential for an analysis of social, political and economic dynamics at different levels. We employed different random effects longitudinal regression models on a long unbalanced panel dataset, using the software STATA. ${ }^{14}$

We begin with a descriptive analysis of the trend of stateness (Fig. 1). During the period of observation (1960-2009), our measure of state capacity has increased everywhere, especially in countries where the quality of democratic governments has been intermediate to strong and the left has exercised power for significant periods of time, as in Chile, Trinidad and Tobago, Uruguay, Brazil and Costa Rica. 
However, equal or slightly less prominent increases in state strength have also occurred where governments were controlled equally by left and right parties, as in Panama, or mostly by parties of the right, as in Colombia and Guatemala. In addition, left executives have played a role where state capacity has increased the least, as in Guyana, Jamaica or Venezuela, countries characterized by diverse levels of democratic quality. In short, no clear indication on the possible links between stateness, democracy and political partisanship comes from a reading of these data alone.

This impression is strengthened by a graphic assessment of the way stateness has changed over time in specific countries: in Chile the authoritarian Pinochet era (1973-1990) is associated with an increase in stateness, especially until 1981 (Fig. 2). Democracy further intensifies state capacity, but the more prominent rise occurs under moderate Christian democratic presidents (1990-2000) rather than under their progressive colleagues within the Concertación alliance (2000-2010). In Uruguay the military period (1973-1985) also corresponds to an increase in stateness, which is maintained and enhanced by the following democratic governments, led by centrist and conservative Colorado and Blanco presidents (1985-2005): their contribution to state capacity is difficult to distinguish from that of the Frente Amplio (Fig. 3). In other cases, as in Paraguay, the growth of state capacity coincides with the authoritarian rule of General Stroessner, especially between 1960 and 1981, while democratic governments (under the guide of the conservative Colorados) were not able, at least until 2009, to improve the stateness scores reached in 
1981 by the tyrant (Fig. 4). In the case of Venezuela, finally, improvements of state capacity were experience both under conservative and progressive democratic governments, as with Copei (Comité de Organización Política Electoral Independiente) president Caldera between 1969 and 1974 and MVR (Movimiento V [Quinta] República) president Chàvez between 2002 and 2009 (Fig. 5). Again, it is hard to discern a clear-cut pattern emerging from this information.

A more refined investigation is in order. In Tab. 1 we analyze 3 models: in the first two, we focus separately on levels of democracy and the impact of executives’ ideological leanings, along with control variables. Subsequently, we estimate the aggregate bearing of these variables on the dependent variable. Specifically, in the first model we regress the indicator of state capacity against levels of democracy (in linear and quadratic forms) controlling for context variables: a lagged (fifteen years) stateness variable; a measure of democratic duration (again in linear and quadratic forms); level of economic development; economic growth over the previous 5 years; oil rents; Gini values; form of government and ethnic fractionalization. Results show that democratic quality (but not democratic duration) has contributed to strengthen stateness in the area between 1975 and 2009 (Rsq=0.667). In the second model, we insert executive partisanship which shows a curvilinear association with stateness: moving from left to right governments, stateness increases first and then declines, as expected (Rsq=0.647). In model 3, finally, we incorporate levels of democracy and executive partisanship along with our control variables and observe that our main results are confirmed (Rsq=0.674). More 
precisely, authoritarian governments and both closed and open anocracies are associated with negative stateness: however, as political regimes get freer and more effective, approaching the threshold of democracy in the Polity IV scale (value 16 in Fig. 6), the impact on stateness becomes positive.

Our main findings suggest that democratizing always benefits stateness: however, the impact of regimes becomes positive only when a significant level of political opening is reached. Democracy fosters an efficient state through a series of mechanisms that reduce violent conflict and establish forms of steering and control from below, as a free press and an independent civil society; by way of instruments of policy control that promote administrative capacity; and by institutionalized procedures and incentives that reinforce the accountability structure. Yet, democratic institutions must be put in place and be effective. Empirical results fit our predictions on executive partisanship as well (Fig. 7). Moving from left executives (points 0 and 1 ) to executives of the center-left (points 2 and 3) the impact of partisanship proves positive but decreasing. Under center right and right executives (points from 4 to 7 ) the impact becomes negative, but the relationship is statistically significant only for rightwing executives. ${ }^{15}$ In short, not only we confirmed the expected causal direction, but also determined that the effects of our independent variables developed at values identifying relevant qualitative conditions: democratic governments in the Polity IV scale and left and left-leaning governments in Coppedge’s taxonomy (Figures 6 and 7). 
In addition, state capacity at 15 years shows significant and positive, meaning that earlier stateness levels have a bearing on current levels. Both economic development and economic growth have a positive sway on stateness, as expected, while oil rents display a positive sign, against predictions: instead of smothering political representation and weakening tax collection as the prevailing theories anticipate, oil proceeds appear to have stimulated stateness in the area (especially in Brazil, Mexico, Venezuela, and Colombia) possibly through public investments, expenditures and the overall contribution to economic wealth, or else these positive effects have been stronger than those classically underlined by the literature. Presidential regimes, finally, look more favorable to state capacity that parliamentary ones, as foreseen, while democratic duration, ethnic fractionalization and Gini values fail to reach statistical significance.

In short, the argument presented here is that democracy and left governments promote the limitation of social and economic prerogatives, thus contributing to a strengthening of state capacity. The adoption and implementation of governments' policies face constraints, including policy capture by powerful social factions and opposition by organized interest groups. Democratic regimes with good development outcomes attempt to surmount such limitations by engaging citizens more actively with the purpose of building the needed consensus for state policies: such participation improves the capacity to allocate resources more equally and effectively and reduces the costs involved in policy enforcement. Thus, the recognition of the right to question policies and make petitions has 
been crucial to the strategies of state capacity building in Latin American democratic regimes. Whereas democracies offer chances for participation and contestation in the policy process, however, redistributive results cannot be taken for granted: it is through the decisive involvement of left governments that the mismatch between political and social powers has been drastically reduced and state strength has increased in the area. This argument emphasizes the importance of reallocating social and political power in favor of subordinate groups so as to construct bureaucratic capacities that reinforce both growth and redistribution and defeat pressures from privileged strata, which repeatedly defy redistributive policies. Social transfers are a vital component of such agreements.

Accordingly, the states usually classified by the literature as the most capable in the region have tended to coincide with the most vigorous democracies, as Costa Rica and Uruguay, along with Chile and Argentina (Cárdenas, 2010; Centeno, 2009). In the first three, progressive parties intent on redistribution were crucial in the process of welfare state building (Grassi, 2014). More generally, redistributive politics have been more inclusive when rural-urban alliances that included a large part of the working poor have been struck, permitting to expand welfare rights to most citizens. In these countries, progressive political parties have promoted the adoption of social rights, and groups have connected with the state as rights-bearing citizens rather than clients. Disputed elections, sometimes leading to alternation in power, encouraged these parties to maintain their social movement features, which in turn showed crucial for upholding 
sympathetic links with the poor. In addition, at the end of the 1990s, a 'new left' has appeared in the subcontinent, which assumed the essential tenets of market economics, while approving reforms such as the enactment of welfare plans for the underprivileged; a new concern for public safety; a more dynamic role for the state as overseer and arbitrator between capital and labor; the expansion and improvement of public services; and the introduction of a more progressive tax system (Barrett et al., 2008, 22).

Our conclusions are partly in line with, and partly supplement, the scant literature on these issues. We developed the only previous analysis on this topic in Latin America (Grassi and Memoli, forthcoming) suggesting that, over extended periods of time, democracy has played a greater role than previously acknowledged: from 1975 to 2009 democratic governments, compared to autocracies and anocracies, did contribute to make stateness more robust. We also confirmed the impact of executives' partisanship, showing in greater detail the bearing of different political leanings on state capacity. Previous authors had argued that the weakness of the state in Latin America depended on pervasive economic inequality: economic inequality, however, is also a reflection of left parties’ weakness, and we illustrated the mechanisms relating these parties to state capacity (Cárdenas, 2010). For Haggard and Kaufmann (2008), democracy may fortify the state by endorsing more progressive social welfare schemes. In the region, in turn, more progressive social welfare systems have been linked to the existence of a stronger left: left governments have more forcefully sponsored redistributive welfare 
and checked the intentional boycotting of critical state powers, such as tax extraction, which infringed upon the privileges of local elites (Grassi, 2014).

Tab. 1 Here

The case of Chile may help illustrate the argument. The leftleaning governments led by presidents Lagos (2000-2006) and Bachelet (2006-2010) deeply reformed education, public health, social security and pensions, greatly enhancing social assistance for Chile's poorest citizens; approved a series of laws on integrity (2003) and transparency (2009) in the Public Administration; diminished the number of civil servants directly chosen by the Executive; and inaugurated a Senior Management Service System, whose access was regulated by competitive public exams, making civil service careers more professional. In 2005, a reform also enhanced the Constitutional Tribunal's autonomy and jurisdiction regarding the constitutionality of laws and administrative acts, making it one of the most powerful tribunal in the world, able to stop governments' decrees and protect citizens' rights against powerful private groups. The armed forces' special privileges over elected politicians, in addition, were drastically cut (Bertelsmann Stiftung, 2010). ${ }^{16}$

One of the most important social reforms promoted by left governments in Chile was president Lagos’ Plan de Acceso Universal con Garantías Explícitas (Regime of Explicit Health Guarantees Plan), also labelled 'Plano AUGE' from its acronym. The plan 
intended to further the quality and accessibility of public sector health services, especially for the least advantaged, by supplying universal medical assistance to people meeting certain age requirements and suffering from one of a set of itemized diseases (initially 25, currently 80). In addition it established new standards for both the quality and quantity of the services provided: these constituted a specific social right to which all citizens were entitled and that the state guaranteed both legally and financially. The law also set maximum waiting times for the delivery of medical treatment and ensured that the required procedures and technologies were offered by qualified health professionals (Missoni \& Solimano, 2010). This reform, finally, was supplemented by an information system and by specific analyses to evaluate compliance monitoring and impact assessment. To sum up, a series of institutions and practices were organized and reinforced, which have been customarily related to capable states.

Our claim does not imply that right governments are unable to strengthen state capacity. In the last decades, state capacity has increased under right governments in Colombia (see Fig. 1). While the extent of their achievements remains unclear (Feldmann, 2012), right executives helped to rebuild domestic order by curbing both political and common violence. Following Uribe’s peace talks with the AUC, quite a few paramilitary leaders have been imprisoned and a dozen major commanders have been extradited to the United States: authorities initiated a demilitarization process that turned into the dissolution of an intimidating armed force. In addition, homicides have dropped from about 28,000 in 2002 to 15,000 in 2010, while tax 
extraction capacity has increased from 10.9 per cent of GDP in 1990 to 17.8 per cent of GDP in 2009, reaching a top of 18.2 per cent in 2006 (Gómez Sabaini and Jiménez 2012, 13). ${ }^{17}$ In 2004, lastly, a civil service law ended five years of legal uncertainty, in which provisional selections affected 38 percent of personnel, introducing new merit based criteria for admission (Grindle, 2010, 22). In short, right governments were able to expand overall state capacity by fortifying domestic order and developing other key stateness dimensions.

\section{Conclusions}

Our investigation set up to determine the impact of democracy and political partisanship on stateness in Latin America between 1975 and 2009. We found that democracy does propel state capacity: while the progressive opening of political regimes contributed to lessen the negative impact of autocracies and anocracies, only democratic regimes exercised a positive bearing on stateness. In a similar manner, our hypothesis on the effects of the partisan composition of government was proven correct: only left and left leaning governments were found to have a positive and significant impact, while other executives did not show a discernible trend, except for the most conservative governments which did play a negative role. The almost perfect fit between our empirical findings and the expected outcomes greatly strengthens these conclusions, which can be enunciated not only in quantitative and relative terms, but also 
qualitatively with reference to the concepts of democratic regimes, on the one hand, and left and left-leaning executives on the other.

Although operating at times as self-interested actors, Latin American parties and governments pursue objectives which are valued by their electoral bases and that differentiate them and their policy positions. Through the mechanisms outlined above and following elaborate historical processes, they have come to develop policies and strategies that have a bearing on the complex course of state formation and change. Whereas not always linear or univocal, the policies developed by left and left-leaning executives appear to have strengthened stateness in the area more than the policies implemented by right and right-leaning governments, reflecting the organizational and ideological ties linking governments and parties to particular constituencies and organized interest groups. From a methodological standpoint our claim is that, by underlining the links between public policies and state capacity and offering an evaluation of executives' partisanship, our investigation goes beyond the analysis of formal state institutions and delves into a deeper and richer political inquiry, grounded on a political economy of state capacity that takes into account the role of social groups, such as urban labor or the middle classes, and their interactions, as reflected by the presence and workings of political parties which these groups represent and act for.

Our study adds to a new line of inquiry relating democracy, political partisanship and stateness. Although in its infancy, this path promises to shed some light on this intricate relationship, resting on the delicate balance of politics, economics and society: it does so by 
articulating a more complete and credible story about the ways power is shared and shaped in society and how these interactions affect the forms and contents of state capacity in contemporary Latin America. The exploration of these issues represents a propitious avenue of investigation for the years to come. 


\section{NOTE}

In this article we will use the terms state capacity, state capability and stateness as equivalent (Fukuyama, 2005).

${ }^{2}$ A fourth more controversial dimension relates to state legitimacy, understood as the rightful exercise of power as recognized by voters. This component has often been considered instrumental to state capacity, rather than one of its essential features (Levi, 2002, 40). Legitimacy levels, in fact, are sometimes higher in authoritarian countries, as China or Azerbaijan, than in democratic ones, as France or New Zealand (Gilley, 2006, 517). Some authors, in addition, find that legitimacy rights, operationalized as broad approval of a government's rights to oblige people to pay taxes, are not related to political rights (Levi \& Sacks, 2009, 326). We finally excluded legitimacy from our operationalization of stateness, since introducing this dimension may lead to endogeneity problems when analyzing the democracy-stateness nexus.

${ }^{3}$ In line with the observations above, special attention is demanded to researchers to avoid conflating the ability to administer from the services themselves and the policy choice to tax from the ability of the state collection apparatus to collect the assessed taxes.

4 We exclude other measures of democracy, for instance the Mainwaring and Brinks index (2007), as these authors use critical elements of our dependent variable, such as political order, to define the presence and strength of democracy in the area, generating endogeneity problems. These authors qualify Colombia (1980s to the present) and Peru (1980s and early 1990s) as undemocratic, given the 
government's and paramilitary's campaigns against guerrillas and drug trafficking carried out during this period (Ibid.: 7). The measure suggested by Huber et al. (2012) conversely, is structured around four regimes types (Authoritarian Regimes, Bureaucratic Authoritarian Regimes, Restricted Democracies and Full Democracies) which drastically restrict our analysis to two categories of democracy.

${ }^{5}$ Relatively wealthy, enduring and sound democracies exhibit lower levels of internal conflict and are associated with lower chances to resort to political violence (Collier \& Rohner, 2008). Yet, Mansfield and Snyder (2005) argue that countries in transition to electoral politics are particularly inclined to civil war, revolution, and ethnic and sectarian hostility.

${ }^{6}$ In most Latin American countries, political parties tend to be less established and their ideologies and electoral pledges less clearly articulated than in the industrialized West: however, experts ordered them into the same left, center-left, center, center-right, and right political spectrum, along with an additional category of personalist parties (, 1997; Huber et al., 2006, 949).

${ }^{7}$ Scholars emphasize the presence of many "lefts" in Latin America, differentiating between a programmatic left (as in Brazil, Chile, Uruguay) and a non-programmatic left (as in Argentina and Bolivia), though they are not always explicit about this (Pribble, 2013; Levitsky \& Roberts, 2013; Weyland \& Gates, 2011; and Cameron \& Hershberg, 2010). This taxonomy is important, since it is sensible to assume that only a programmatic left party would invest in building state capacity. When parties are not programmatic, electors are not oriented towards 
programs in their voting, it is problematic to hold leaders responsible, and incumbents have no motivation to translate electoral pledges into effective policies. Our operationalization (Huber et al., 2012), is largely in line with this distinction.

${ }^{8}$ We assessed the partisan orientation of government recoding the variable in the following way: 0 for left through 8 for right governments (Huber et al., 2006). This measure has been labeled “Executive Partisan Balance”.

${ }^{9}$ In Latin America, a 14 years period corresponds roughly to three presidential terms (Martinez-Gallardo, 2011, 13).

${ }^{10}$ Duration refers to the uninterrupted number of years of existing democratic systems, taking 1945 as the first year in our time series.

${ }^{11}$ Countries where oil rents are less than 10 per cent of GDP were coded 0 ; and countries where oil rents are superior to 10 per cent of GDP were coded 1.

12 For some, ethnic composition does not fuel violence and fragmentation automatically; it does so, only when trigger factors, such as unscrupulous leadership; opportunistic neighbors; and shattered or growing hopes detonate structural contradictions (Gurr 1994).

${ }^{13}$ Namely: Argentina, Bahamas, Barbados, Belize, Haiti, Jamaica and Suriname. The countries finally included are: Bolivia, Brazil, Chile, Colombia, Costa Rica, Dominican Republic, Ecuador, El Salvador, Guatemala, Guyana, Honduras, Mexico, Nicaragua, Panama, Paraguay, Peru, Trinidad and Tobago, Uruguay and Venezuela. 
${ }^{14}$ As we found some heteroskedasticity, we employed cluster-robust standard errors, which yield a consistent VCE estimator (see Arellano, 2003; Stock \& Watson, 2008; Wooldridge, 2009).

${ }^{15}$ In their classification of political parties in the area, Coppedge (1997) and Huber et al. (2012) distinguish between secular and Christian parties. Point 7 in Figure 7 corresponds to Christian rightwing executives.

${ }^{16}$ During this period, tax collection grew slightly, by about 1 percent (Gómez \& Jiménez, 2012, 13).

17 Flores-Macias (2014) claims that security crises in Colombia provided right parties a unique window of opportunity to strengthen tax capacity, as illustrated by president Uribe’s adoption, in 2002, of the so-called "war tax", which can be considered as one of Colombia's most important policy responses to the FARC challenge. 


\section{$\underline{\text { References }}$}

Acemoglu, D. \& Robinson, J. (2008). The Role of Institutions in Growth and Development Commission on Growth and Development Working Paper No.10. Washington DC: World Bank.

Adserà, A., Boix, C., \& Payne, M. (2003). Are You being Served? Political Accountability and Quality of Government. The Journal of Law, Economics and Organization, 19(1), 445-90.

Arellano, M. (2003), Panel Data Econometrics. Oxford: Oxford University Press.

Ben-Meir, A (2006). Challenges to Democracy in the Arab and Muslim World. Review of International Law and Politics, 6, 105-110.

Bäck, H., \& Hadenius, A. (2008). Democracy and state capacity: exploring a J-shaped relationship. Governance, 21(1), 1-24.

Barret, P., Chavez, D., \& Rodríguez-Garavito, C. (Eds.) (2008). The Latin American Left: Utopia Reborn. London: Pluto Press.

Bates, R. H. (2008). When things fell apart: state failure in late-century Africa. Cambridge: Cambridge University Press.

Bertelsmann Stiftung (2010). Bertelsmann Transformation Index 2010 Politische Gestaltung im internationalen Vergleich. Gütersloh: Verlag Bertelsmann Stiftung.

Besley, T., \& Persson, T. (2009). The Origins of State Capacity: Property Rights, Taxation and Politics. American Economic Review, 99(4), 1218-44.

Bueno de Mesquita, B., Downs, G. W., Smith, A., \& Cherif, F. M. (2015). Thinking Inside the Box: A Closer Look at Democracy and Human Rights. International Studies Quarterly, 49, 439-457. 
Bratton, M. (2008). Do free elections foster capable government? The democracy-governance connection in Africa Afrobarometer Working Paper, 104, 331-354.

Bresser-Pereira, L. (2001. The New Left viewed from the South. In A. Giddens (Ed.), The Global Third Way Debate, Cambridge: Polity Press.

Carbone, G. (2013). Democratisation as a State-Building Mechanism: A Preliminary Discussion of an Understudied Relationship. Political Studies Review, 13(1), 11-21.

Carbone, G., \& Memoli, V. (2015). Does democratization foster state consolidation? Democratic rule, political order and administrative capacity. Governance, 1, 5-24.

Cameron, M. A., \& Hershberg, E. (Eds.) (2010). Latin America's left turns: Politics, policies, and trajectories of change (pp. 98-127). Boulder, Colorado: Lynne Rienner Publishers.

Cárdenas, M., \& Tuzemen, D. (2010). Under-Investment in State Capacity: The Role of Inequality and Political Instability. Global Economy and Development. Washington D. C.: Brooking.

Cárdenas, M. (2010). State Capacity in Latin America. Economía, 10(2), 145.

Centeno, M. (2009). El Estado en América Latina. Revista Cidob d'Afers Internacionals, 85-86, 11-31.

Charrón, N., \& Lapuente, V. (2010). Does democracy produce quality of government?. European Journal of Political Research, 49(4), 443470. 
Cheibub, J. (1998). Political Regimes and the Extractive Capacity of Governments: Taxation in Democracies and Dictatorships. World Politics, 50(3), 349-376.

Collier, P., \& Rohner, D. (2008). Democracy, Development and Conflict. Journal of the European Economic Association, 6(2-3), 531-40.

Coppedge, M. (1997). A Classification of Latin American Political Parties Kellogg Institute Working Paper \#244. Paris: Notre Dame.

Dahl, R. (1989). Democracy and its Critics. New Haven: Yale University Press.

Diamond, L. J. (2002). Thinking about hybrid regimes. Journal of democracy, 13(2), 21-35.

Engerman, S. L., \& Sokoloff, K. L. (2002). Factor endowments, inequality, and paths of development among new world economics NBER Working Paper No. 9259. National Bureau of Economic Research.

Feldmann, E.A. (2012). Measuring the Colombian "Success" Story. Revista de Ciencia Política, 3, 739-52.

Flores-Macías, G.A. (2014). Financing Security Through Elite Taxation: The Case of Colombia's "Democratic Security Taxes. Studies in Comparative International Development, 49(4), 477-500.

Fortin, J. (2010). A tool to evaluate state capacity in post-communist countries, 1989-2006. European Journal of Political Research, 49(5), 654-686.

Fukuyama, F., \& Colby, S. (2011). Half a miracle Foreign Policy, May/June, Available at http://www.foreignpolicy.com/articles/2011/04/25/half_a_miracle. 
Fukuyama, F. (2007). Liberalism versus State-Building. Journal of Democracy, 18(3), 10-13.

Fukuyama, F. (2005). Stateness first. Journal of Democracy, 16(1), 84-88.

Gilley, B. (2006). The determinants of state legitimacy: Results for 72 countries. International Political Science Review, 27(1), 47-71.

Gómez S., Carlos, J., \& Jiménez, J. P. (2012). Tax structure and tax evasion in Latin America Paper 118, Serie macroeconomía del desarrollo, Cepal.

Grassi, D. (2014). Democracy, social welfare and political violence: the case of Latin America. Journal of International Relations and Development, 17(2), 242-273.

Grassi D., \& Memoli, V. (2016), Democracy, Political Partisanship and State Capacity in Latin America. Italian Political Science Review (forthcoming).

Green, W.H. (2008). Econometric analysis (6th ed.). Upper Saddle River, New Jersey: Prentice Hall.

Grindle, M.S. (2010). Constructing, Deconstructing, and Reconstructing Career Civil Service Systems in Latin America HKS Faculty Research Working Paper Series, RWP10-025, John F. Kennedy School of Government, Harvard University.

Grzymala-Busse, A. (2007). Rebuilding Leviathan: Party Competition and State Exploitation in Post-communist Democracies. New York, NY: Cambridge University Press.

Gurr, T. R. (1994). Peoples against states: Ethnopolitical conflict and the changing world system: 1994 presidential address. International Studies Quarterly, 38, 347-377. 
Gutiérrez, F. (2011). Evaluating state performance: a critical view of state failure and fragility indexes. European Journal of Development Research, 23(1), 20-42.

Haggard, S. and R.R. Kaufman (2008), Development, Democracy and Welfare States, Princeton, Princeton University Press.

Hagopian, F., and S. Mainwaring (2005), The Third Wave of Democratization in Latin America: Advances and Setbacks, Cambridge, Cambridge University Press.

Hanson, J.K. and R. Sigman (2013), Leviathan's Latent Dimensions: Measuring State Capacity for Comparative Political Research, Manuscript, Maxwell School of Citizenship and Public Affairs, Syracuse University.

Hendrix, C. (2010), Measuring state capacity: theoretical and empirical implications for the study of civil conflict, «Journal of Peace Research», 47, 3, pp. 273-285.

Herbst, J. and G. Mills (2006), Africa’s big dysfunctional states : an introductory overview, in C. Clapham, J. Herbst and G. Mills (eds), Big African states. Johannesburg, Wits University Press.

Huber, E. and J.D. Stephens (2012), Democracy and the Left: Social Policy and Inequality in Latin America, Chicago, University of Chicago Press.

Huber, E., J. Stephens, J., T. Mustillo and J. Pribble (2012), Latin America and the Caribbean Political Dataset, 1945-2008, Available at http://www.unc.edu/ jdsteph/documents/common/data/Codebook_LA C_Political_2012.doc. 
Huber, E., F. Nielsen, J. Pribble and J.D. Stephens (2006), Politics and Inequality in Latin America and the Caribbean, «American Sociological Review», 71, 6, pp. 943-63.

Huber, Evelyne, and John D. Stephens (2001). Development and crisis of the welfare state: parties and policies in global markets. Chicago: University of Chicago Press.

Karl, T. (2004), Encyclopedia of Energy, Vol. 4. R., Elsevier Inc.

Levitsky, S., and Roberts, K. M. (Eds.). (2013). The resurgence of the Latin American left. Maryland: JHU Press.

Levitsky, S., Way, L. (2002). The Rise of Competitive Authoritarianism. Journal of Democracy, 13(2), 51-65.

Levi, M. (2002). The State of the Study of the State. In I. Katznelson, \& H. Milner (Eds.), Political Science: The State of the Discipline, London: APSA/Norton.

Levi, M., \& Sacks, A. (2009). Legitimating Beliefs: Sources and Indicators. Regulation \& Governance, 3(4), 311-33.

Mainwaring, S., Brinks, D. M., \& Pérez-Liñán, A. (2007). Classifying political regimes in Latin America, 1945-2004. In S. Mainwaring, D. M. Brinks, \& A. Pérez-Liñán, (Eds.), Regimes and Democracy in Latin America. Theories and Methods. New York: Oxford University Press.

Mann, M. (2008). Infrastructural power revisited. Studies in Comparative International Development, 43(3-4), 355-365.

Mansfield, E., \& Snyder, J. (2005). Electing to Fight: Why Emerging Democracies Go to War. Cambridge, MIT Press. 
Marshall, M. G., Cole, B. R. (2014). Global Report 2014 - Conflict, Governance, and State Fragility. Vienna: Center for Systemic Peace.

Martinez-Gallardo, C. (2011). Designing cabinets: presidential politics and cabinet instability in Latin America Kellogg Institute Working Paper 375, University of Notre Dame.

Mata, J. F., \& Ziaja, S. (2009). Users' Guide on Measuring Fragility. Bonn: German Development Inst..

Merkel, W. (2001). Embedded and Defective Democracies Paper presented at the Meeting of the American Political Science Association, Washington, D.C.

Missoni, E., \& Solimano, G. (2010). Towards universal health coverage: the Chilean experience World health report, Background Paper, 4, World Health Organization, Switzerland, Geneva.

Nelson J. (2007). Elections, Democracy and Social Services. Studies in Comparative Development, 41(4), 79-97.

O’Donnell, G. (1993). On the State, Democratization, and Some Conceptual Problems: A Latin American View with Some Glances at PostCommunist Countries. World Development, 21(8), 1355-69.

Pellegrini, L., \& Gerlagh, R. (2008). Causes of corruption: a survey of crosscountry analyses and extended results. Economics of Governance, 9, 245-63.

Pribble, J. (2013). Welfare and party politics in Latin America. New York: Cambridge University Press.

Rangel, A. (2005). Sostenibilidad de la Seguridad Democrática. Bogotá: Fundación seguridad y democracia. 
Rauch, J. E., \& Evans, P. B. (2000). Bureaucratic structure and bureaucratic performance in less developed countries. Journal of public economics, 75(1), 49-71.

Saylor, R. (2012). Sources of state capacity in Latin America: commodity booms and state building motives in Chile. Theory and society, 41(3), $301-324$

Schumacher, G., \& Vis, B. (2009). Party Organization, Electoral Competition and Reform of Welfare State Generosity in OECD Countries, 1973-2002 Paper Prepared for the Annual Meeting of the APSA, Toronto, September 3-6.

Sikkink, K. (1991). Ideas and Institutions: Developmentalism in Brazil and Argentina. Ithaca: Cornell University Press.

Slater, D. (2008). Can Leviathan be democratic? Competitive elections, robust mass politics and state infrastructural power. Studies in Comparative International Development, 43, 252-272.

Sojo, C. (2011). The State under scrutiny: Public opinion, Stateness and government performance in Latin America, Santiago de Chile: Cepal.

Soifer, H.D. (2012). Measuring State Capacity in Contemporary Latin America, Revista de Ciencia Política, 32(3), 585-98.

Stock, J., \& Watson, M. (2008). Heteroskedasticity-robust standard errors for fixed effects panel data regression. Econometrica, 76, 155-174.

Svolik, M. W. (2012). The Politics of Authoritarian Rule. New York, YU: Cambridge University Press.

Weber, M. (1978). Economy and Society. Berkely: University of California Press. 
Weyland, K., \& Gates, L. C. (2011). Electing Chávez: The Business of AntiNeoliberal Politics in Venezuela. Perspectives on Politics, 9(2), 464.

Zakaria. F. (1997). The Rise of Illiberal Democracy. Foreign Affairs, 76, 6, 22-43.

Wang, E. H., \& Xu, Y. (2015). Awakening Leviathan: The Effect of Democratization on State Capacity, 1960-2009." Available at SSRN 2626849 (2015).

Wooldridge, J. (2009). Introductory Econometrics: A Modern Approach, 4th ed., Cincinnati, Ohio: South-Western. 